\title{
20. A REGIONAL PERSPECTIVE OF SHALLOW-BURIAL DIAGENESIS OF DEEP-WATER PERIPLATFORM CARBONATES FROM THE NORTHERN BAHAMAS1
}

\author{
George R. Dix ${ }^{2}$ and Henry T. Mullins ${ }^{2}$
}

\begin{abstract}
Detailed studies of carbonate mineralogy and geochemistry using samples recovered by deep-sea drilling in the northern Bahamas document shallow-burial ( $<250 \mathrm{mbsf}$ ) diagenetic trends that occur in two stages. Stage 1 diagenesis ( 0 -10 meters below the seafloor, mbsf) results in rapid, extensive calcitization and local dolomitization in marine-derived pore fluids. Stable oxygen isotopes are quickly enriched, while carbon values are depleted. Aragonite undergoes dissolution and high-magnesian calcite exsolves to low-magnesian calcite. Below 10 to at least 185 mbsf, stage 2 diagenesis continues to alter primary components, leading to ooze-chalk and chalk-limestone transformations and low amounts of dolomite, while rates and amplitudes of change are considerably less than in stage 1. Oxygen- and carbon-isotope ratios indicate that diagenesis still occurs in marine-derived pore fluids.

Overall, shallow-burial diagenesis of periplatform carbonates proceeds much more readily than diagenesis of deepsea pelagic ooze. This is because of higher diagenetic potential related to the influx of metastable shallow-water-derived components in a deep-marine realm. Subsurface calcitization and lithification of periplatform sediments occurs rapidly with depth in regions of moderate accumulation rates $(20-60 \mathrm{~m} / \mathrm{m}$.y.; north of Little Bahama Bank). This is a result of an interpreted greater rate of diagenetic alteration with burial, and in deep $(3000 \mathrm{~m})$ water is related to seawater saturation levels relative to carbonate mineralogy. Calcitization and local dolomitization may occur at or near the sediment/ water interface during formation of disconformities. In contrast, metastable aragonite and high-magnesian calcite are present in significant amounts at depth in regions with high accumulation rates ( $>90 \mathrm{~m} / \mathrm{m}$.y., Exuma Sound), despite lithification that produces chalk and limestone. The presence of metastable components in porous limestones in Exuma Sound underscores the current high diagenetic potential for these rocks and the development of reservoir potential in periplatform deep-water limestones at shallow sub-bottom depths.
\end{abstract}

\section{DEDICATION}

This paper is dedicated to the memory of H. Mark Van Buren, who, at the age of 36 , died because of medical complications from an automobile accident on January 16, 1986 in San Jose, California. Mark's 1984 Master's thesis- "Seismic Stratigraphy of a Modern Carbonate Slope: Northern Little Bahama Bank"-was the basis for many of the objectives of Leg 101, Sites 627 through 630. Mark's work focused on the now widely cited bathymetry of the deep bank margin north of Little Bahama Bank, as well as on 3.5-kHz echo-character studies and seismic sequence analysis. Mark also discovered Walkers Cay Fault, a prominent northeast-southwest striking fault zone normally oriented to the bank margin of Little Bahama Bank. All these studies influenced both the design and execution of Leg 101 drilling north of Little Bahama Bank.

\section{INTRODUCTION}

Carbonate sediments that accumulate in deep ( $>200 \mathrm{~m}$ ) waters peripheral to carbonate platforms consist of a unique mix of mostly bank-derived aragonite and magnesian calcite plus pelagic calcite. Termed "periplatform ooze" by Schlager and James (1978), the depositional environment of these sediments is transitional between shallow-water platforms and the deep, open ocean. Periplatform ooze possesses a high diagenetic potential (Schlanger and Douglas, 1974) in its depositional environment because of the metastability of aragonite and highmagnesian calcite in deep, cold seawater (James and Choquette, 1983b).

\footnotetext{
${ }^{1}$ Austin, J. A., Schlager, W., et al., 1988. Proc. ODP, Sci. Results, 101: College Station, TX (Ocean Drilling Program).

2 Department of Geology, Heroy Geology Laboratory, Syracuse University, Syracuse, NY 13244-1070.
}

Tropical, shallow-water carbonate sediments also contain large quantities of aragonite and high-magnesian calcite. However, in their primary depositional environment, these minerals are relatively stable because of carbonate saturation or supersaturation of ambient seawater. Once exposed to the meteoric environment (by waters undersaturated with aragonite and magnesian calcite), however, shallow-water carbonates are susceptible to early diagenesis, including dissolution, dolomitization, and lithification (Bathurst, 1975; James and Choquette, 1984). In contrast, deep-sea pelagic ooze consists of relatively stable calcite derived principally from planktonic foraminifers and coccolithophorids. These calcitic deposits resist early diagenesis at water depths above the calcite lysocline and carbonate compensation (CCD) depth. Below the CCD, however, pelagic calcites may be completely removed by dissolution.

Because of the high diagenetic potential of periplatform carbonates, one intuitively expects relatively rapid diagenetic alteration of periplatform carbonates on the seafloor or in shallow subsurfaces. Indeed, previous studies documented extensive surficial submarine diagenesis in high-energy, current-swept, periplatform environments (Mullins et al., 1980) as well as in relatively low-energy, deeper-water settings, where erosion and/or low sedimentation rates resulted in long-term exposure of surficial sediment to seawater (Milliman, 1966; Fisher and Garrison, 1967; Milliman and Muller, 1977; Schlager and James, 1978).

In comparison with shallow-water (Scholle and Halley, 1985) and deep-sea pelagic carbonates (Garrision, 1981), we know little about shallow-burial diagenesis of periplatform carbonates. Because previous studies were restricted to surface grab and/or submersible samples as well as shallow $(<12 \mathrm{~m})$ piston cores, diagenetic models requiring low sedimentation rates or longterm exposure to lithify deep-water carbonates have been overemphasized (James and Choquette, 1983b). 
Based on cores from Tongue of the Ocean (Bahamas), Schlager and James (1978) found that some periplatform ooze in the subsurface retains its original composition for at least 200,000 to $400,000 \mathrm{yr}$. They further proposed that periplatform carbonates remain unlithified for "tens of millions of years." In contrast, by studying cores from the slope north of Little Bahama Bank, Mullins et al. (1985a), discovered that shallow-burial $(<30$ mbsf) diagenesis can result in extensive calcitization and lithification during 400,000 yr. They proposed that periplatform carbonates undergo accelerated rates of burial diagenesis relative to calcitic pelagic carbonates. The recent discovery during Leg 101 of shallow ( $\sim 120 \mathrm{mbsf})$ limestones of late Miocene age at Site 632 in Exuma Sound (Austin, Schlager, et al., 1986), associated with accumulation rates of up to $210 \mathrm{~m} / \mathrm{m}$.y., indicates that the ooze-chalk-limestone transformation can proceed at shallow subbottom depths and does not need to be linked to exposure at the seafloor (Dix and Mullins, unpublished data). From this study and those of Saller (1984, 1986), Mullins et al. (1985a, 1985b), and Freeman-Lynde et al. (1986), substantial alteration, lithification, dissolution, calcitic cement precipitation, and dolomitization at shallow-burial depths can occur in deep-water, marinederived pore fluids.

This paper presents our results about shallow-burial $(<250$ mbsf) diagenesis of Neogene periplatform carbonates in the $\mathrm{Ba}-$ hamas, using cores recovered by the Deep Sea Drilling Project (DSDP) and the Ocean Drilling Program (ODP); see Figure 1. Our approach is a regional perspective in that we have sampled cores from various water depths from three major oceanographic settings defined by Mullins and Neumann (1979). Specific sites and their settings (Fig. 2) include (1) DSDP Site 98 (Hole 98) (Hollister, Ewing, et al., 1972) at a water depth of $2750 \mathrm{~m}$ in Northeast Providence Channel, an open seaway with circulation between the Atlantic Ocean and Florida Straits; (2) Site 626 (Hole 626C) at a water depth of $844 \mathrm{~m}$ in the open seaway of the northern Straits of Florida; (3) Site 630 (Hole 630A), at a water depth of $807 \mathrm{~m}$, along the northern open-ocean margin of Little Bahama Bank facing the Atlantic Ocean; and (4) Site 631 (Hole 631A) at a water depth of $1081 \mathrm{~m}$ in Exuma Sound, a closed seaway, open to oceanic circulation only to the southeast and surrounded on three sides by shallow-water platforms.

In terms of the chemical oceanographic setting, Droxler et al. (in press) recently demonstrated that carbonate lysoclines and compensation depths (for fine fractions) are depressed in the Bahamas relative to the open Atlantic because of bank-top influx. Saturation for high-magnesian calcite occurs between 900 and 1500 meters below sea level (mbsl); between 3800 and 4500 mbsl for aragonite; and about 5550 mbsl for calcite.

\section{METHODS}

Bulk-sediment samples $\left(10 \mathrm{~cm}^{3}\right)$ were collected on board the JOIDES Resolution during Leg 101, as well as from the core repository at Lamont-Doherty Geological Observatory. Cores were sampled at regular 0.5 - to $1.0-\mathrm{m}$ intervals to a depth of $200 \mathrm{mbsf}$ and at $1.0-\mathrm{m}$ intervals at greater sub-bottom depths. More detailed spacing was chosen as needed, based on core descriptions and visual observations.

Samples were split, and one-half was dried at room temperature and powdered by hand grinding. The other half was refrigerated. Powders were analyzed for (1) total carbonate content, using a "Karbonat-Bombe" (Müller and Gastner, 1971); (2) quantitative carbonate mineralogy by $\mathrm{X}$-ray diffraction, using the "peak-area" method and an aragonite correction curve (Milliman, 1974); (3) bulk stable carbon- and oxygen-isotope ratios relative to Peedee belemnite standards; and, (4) magnesium and strontium concentrations of the carbonate fraction by direct-current plasma emission spectrometry after samples were rinsed in distilled water. Part of the nonpowdered splits from selected samples was dried

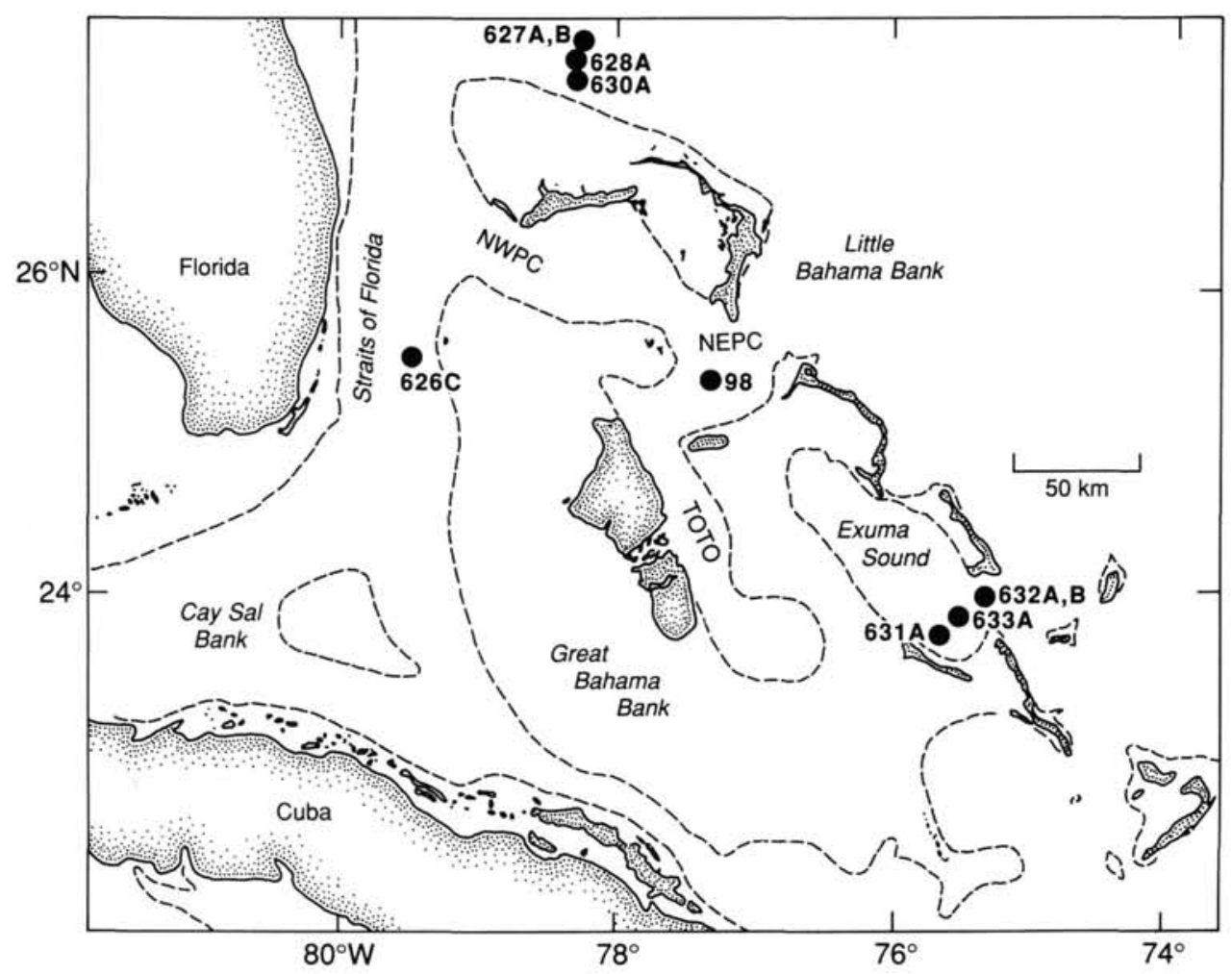

Figure 1. Distribution of ODP and DSDP holes in the Bahamas. Note locations of ODP Holes 626C, $630 \mathrm{~A}$, and 631A and DSDP Hole 98. NWPC $=$ Northwest Providence Channel; NEPC $=$ Northeast Providence Channel; TOTO $=$ Tongue of the Ocean. 

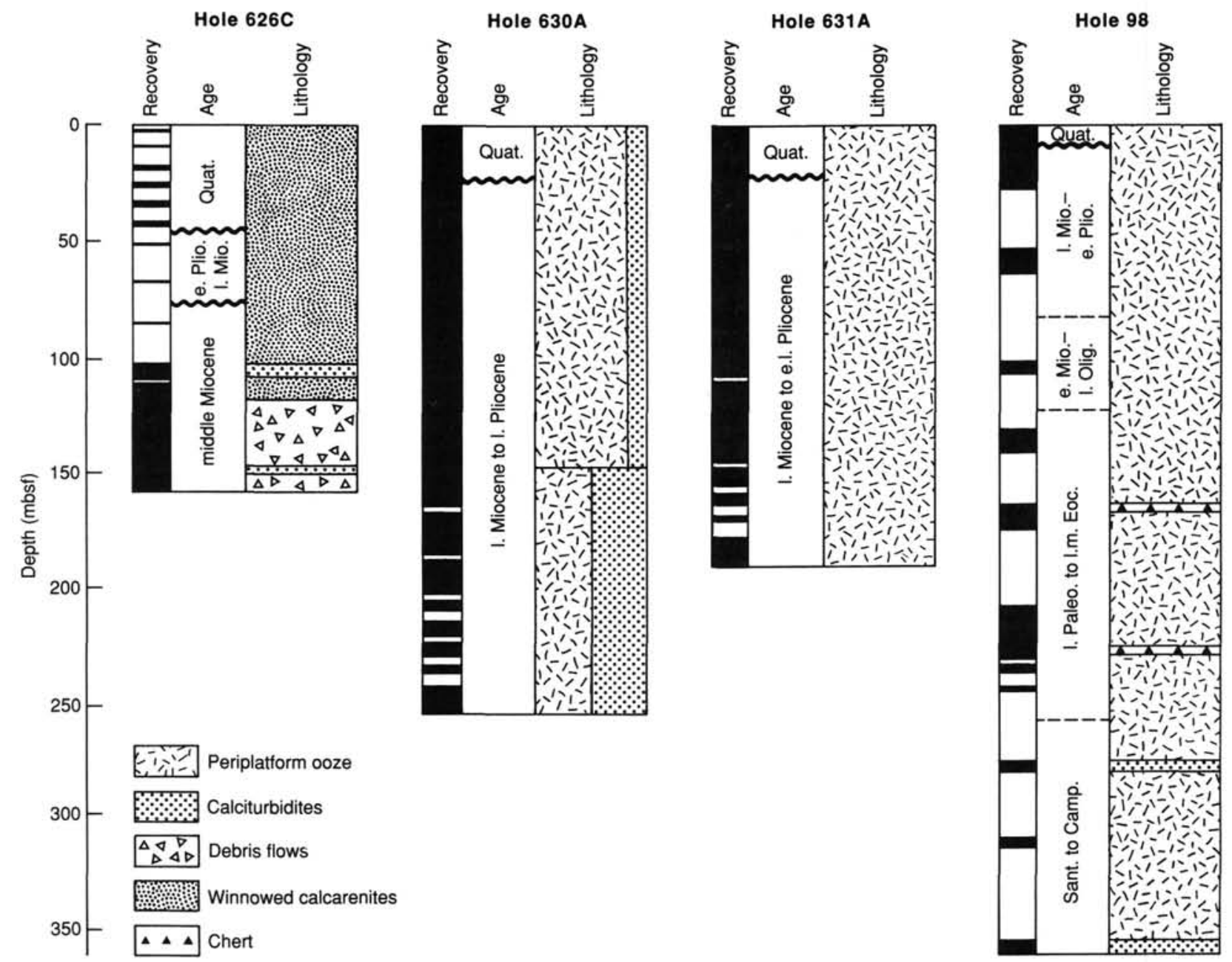

Figure 2. Generalized, schematic descriptions of major lithologic types in ODP Holes 626C, 630A, and 631A and DSDP Hole 98. Recovered core intervals are shown in black.

at room temperature and examined by scanning electron microscopy (SEM). Thin sections of limestones and chalks were stained for magnesian calcite, dolomite, and calcite (Evamy, 1969; Choquette and Trussell, 1978). Our results then were integrated with shipboard biostratigraphic and lithostratigraphic data (Austin, Schlager, et al., 1986).

\section{RESULTS}

\section{Hole 626C, Straits of Florida}

At Site 626 , four holes were drilled with a maximum depth of about 450 mbsf. However, Hole $626 \mathrm{C}$ represents the best penetration relative to recovery (Fig. 2; $179.3 \mathrm{mbsf}, 37 \%$ recovered). Poor recovery and extensive downhole contamination at Site 626 were a result of unstable sandy sediment (Austin, Schlager, et al., 1986). There was, however, good recovery of a thick middle Miocene debris flow deposit extending from about 120 to 170 mbsf. Below 170 mbsf core recovery again was so poor that no samples were analyzed from below this depth.

\section{Lithology}

Most core sediments from Hole $626 \mathrm{C}$ are washed carbonate sands that alternate locally between well-lithified and unlithified grainstones (Figs. 2 and 3 ) and range in age from late Oligocene to Holocene. This rather monotonous sequence is punctuated by a 50 -m-thick debris flow of unlithified floatstones and sandstones (Figs. 2 and 3) between about 120 and 170 mbsf. Based on this sequence, it appears that vigorous flow of the Florida Current has existed since at least the late Oligocene (Austin, Schlager, et al., 1986).

\section{Carbonate Content and Mineralogy}

Total $\mathrm{CaCO}_{3}$ content of core samples ranges from $80 \%$ to $98 \%$, with most samples greater than $95 \%$ (Fig. 4). Although high total carbonate contents were not unexpected, we were surprised that this percentage exceeded $95 \%$. The Florida Current enters the northern Florida Straits from the Caribbean Sea and Gulf of Mexico, where it has ample opportunity to entrain noncarbonate components. This implies that currents may be efficient in transporting terrigenous material and/or that Site 626 is simply overwhelmed by off-bank transportation of carbonate sand from the adjacent, shallow-water, leeward platform margin (Hine et al., 1981).

Our X-ray diffraction data (Fig. 4) indicate that calcite is the dominant carbonate mineral throughout the cores, ranging from $85 \%$ to $95 \%$ and that collectively aragonite, high-magnesian calcite, and dolomite constitute only $10 \%$ to $15 \%$. This contrasts sharply with the modern depositional environment in the northern Straits of Florida, where leeward, off-bank transportation supplies large quantities of metastable, bank-derived arag- 

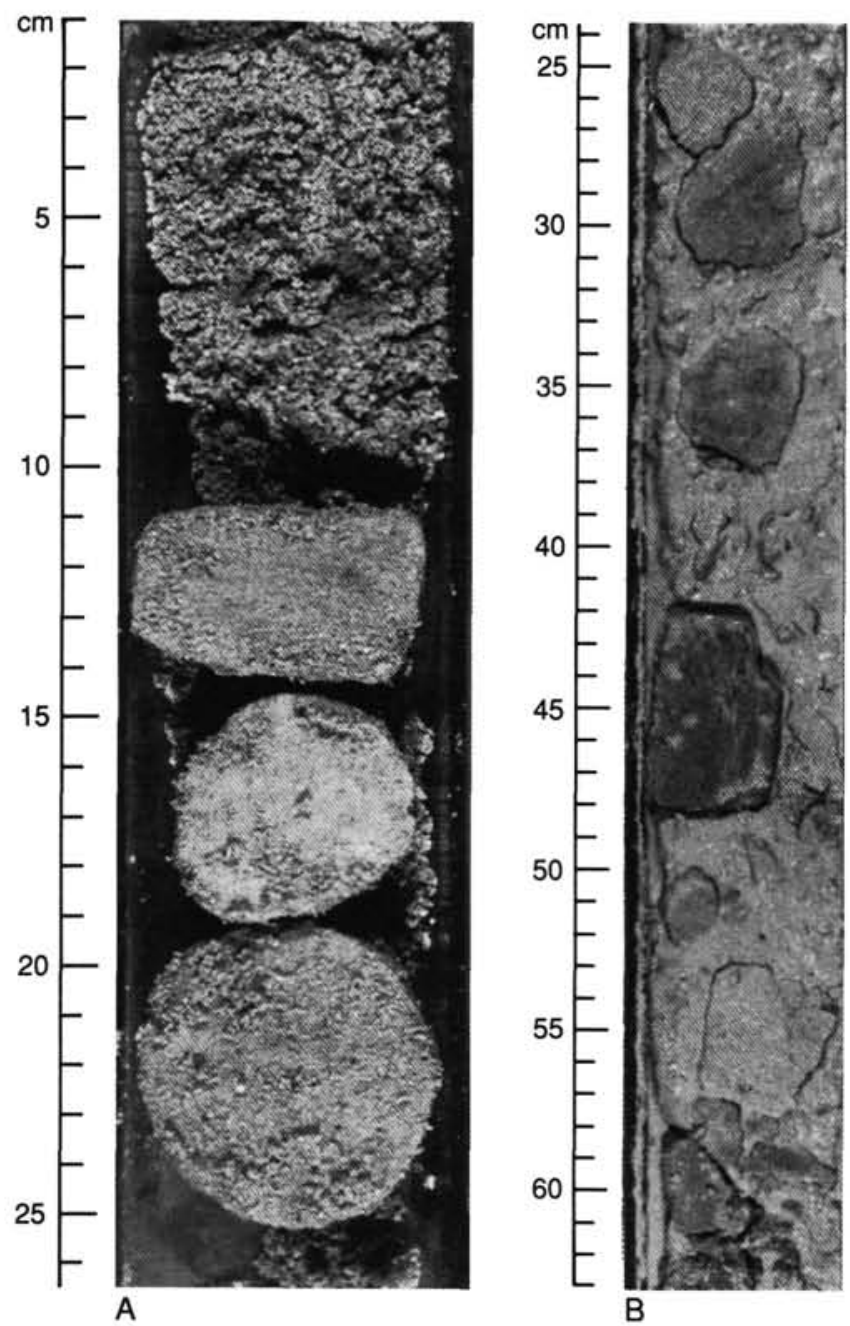

Figure 3. Photographs of cores from Hole 626C. A. Section 101-626C$2 \mathrm{X}, \mathrm{CC}$ : unlithified, current-winnowed carbonate sands overlying wellcemented grainstone equivalents. B. Sample 101-626C-17H-3, 25-63 cm: middle Miocene debris-flow deposit. Scales in $\mathrm{cm}$.

onite and magnesian calcite to deeper waters (Hine et al., 1981). Note that small percentages of metastable aragonite and magnesian calcite persist to a depth of at least $170 \mathrm{mbsf}$, indicating that some diagenetic potential is retained, at least to this level. Small quantities (less than $2 \%$ ) of calcium-rich $\left(56 \% \mathrm{CaCO}_{3}\right)$ dolomite occur sporadically throughout the cores, with an anomalous maximum value of $23 \%$ (Fig. 4) below an interpreted disconformity at 122 mbsf (Austin, Schlager, et al., 1986).

\section{Geochemistry}

Strontium concentrations are uniformly low throughout core samples from Hole $626 \mathrm{C}$, and most values are less than 2000 ppm (Fig. 4). An anomalous maximum value of about $4000 \mathrm{ppm}$ occurs at 149 mbsf, where X-ray diffraction data indicate the presence of celestite $\left(\mathrm{SrSO}_{4}\right)$. These measured strontium concentrations are significantly less than high-strontium ( $7500 \mathrm{ppm})$ aragonite derived today from shallow-water bank tops (Boardman and Neumann, 1984). In general, magnesium values are greater and more variable than strontium concentrations. Magnesium content ranges from about 4000 to $9000 \mathrm{ppm}$, with somewhat higher values in the mid-Miocene debris flow (Fig. 4). A maximum magnesium concentration of $30,000 \mathrm{ppm}$ coincides with the maximum $(23 \%)$ dolomite occurrence at $122 \mathrm{mbsf}$.
Stable carbon-isotope ratios are constant throughout cores from Hole $626 \mathrm{C}$, varying from only -0.5 to $+1.5 \%$. These values suggest carbon that derived from a marine reservoir (Hudson, 1977). In contrast, stable oxygen ratios are more variable, ranging from 0 to $+3.3 \%$ (Fig. 4). The largest departures in $\delta^{18} \mathrm{O}$ occur between adjacent unlithified and lithified grainstones, with lithified material about $3 \%$ heavier than unlithified counterparts. We view these collective isotope data as indicators of diagenetic equilibration in deep, cold, marine waters.

\section{Petrographic Characteristics}

Thin sections reveal that allochems consist of abundant planktonic foraminifers and cryptocrystalline grains, common lithoand intraclasts, minor benthic foraminifers, echinoid spines and plates, red algae, and fragments of Halimeda (Fig. 5). The highly degraded nature of many grains may be inherited from their source along the leeward, shallow-water bank margin of Great Bahama Bank (Hine et al., 1981) and/or current-controlled exposure on the floor of the Straits of Florida before burial. Microprobe analysis of red algae having a well-preserved internal structure indicates a $\mathrm{MgCO}_{3}$ composition of less than $4 \mathrm{~mol} \%$. This suggests exsolution of magnesium from the crystal lattice (Gomberg and Bonatti, 1970) either on the seafloor or in the shallow subsurface. Cement occurs as both high-magnesian calcite and calcite void fill (Fig. 5). Magnesian calcite also forms syntaxial overgrowths around echinoid fragments, whereas microcrystalline calcitic cement occurs as rims around other allochems. Micrite rinds also are common, produced by endolithic microborers in shallow- and/or deep-water environments (Hook et al., 1984).

Dolomite occurs in a variety of forms, including (1) isolated, euhedral crystals; (2) intraskeletal void fill; (3) rounded mosaics (Figs. 5D and 5E) of detrital origin, as indicated by truncation of crystals at the mosaic edge; and (4) in-situ mosaics, as either void fills or replacements of calcite (Figs. 5F and 5G). Dolomite types 3 and 4 suggest rapid dolomitization, followed by reworking, which indicates dolomitization at shallow sub-bottom depths or at the sediment/water interface.

\section{Site Summary}

Various measured and observed parameters suggest that extensive diagenesis occurred in equilibrium with cold, marine waters either at the sediment/water interface or at shallow-burial depths ( $<170 \mathrm{mbsf})$ of the current-swept northern Straits of Florida. The presence of well-indurated grainstones and packstones with enriched $\delta^{18} \mathrm{O}$ values at shallow-burial depths (e.g., $7 \mathrm{~m}$ ) is the most obvious and convincing evidence. Poor core recovery prohibits a more exact definition of the depth of lithification. The absence of obvious hardgrounds associated with lithified intervals (Austin, Schlager, et al., 1986) suggests a shallow-burial depth for cementation. Core samples from Hole 626C are predominantly calcite and lack appreciable quantities of aragonite or high-magnesian calcite at even the shallowest sub-bottom depths, despite the proximity of shallow-water platforms and leeward off-bank transportation into the Florida Straits.

\section{Hole 98, Northeast Providence Channel}

\section{Lithology}

DSDP Site 98 is located at a water depth of $2750 \mathrm{~m}$ (Hollister, Ewing, et al., 1972). Selective intervals that were drilled in 1970 were cored to a depth of 357 mbsf, and recovered deep-water carbonates of Late Cretaceous (Santonian) to Holocene age. Cores from the upper $240 \mathrm{~m}$ contained samples of ooze and chalk with a middle Eocene chert zone (layer II of Mullins and Lynts, 1976) at 167 mbsf. Below 240 mbsf, strata consist of chalk and limestone. A disconformity between lower Pliocene and upper Pleistocene sediments occurs at 9.5 mbsf (Fig. 2). 


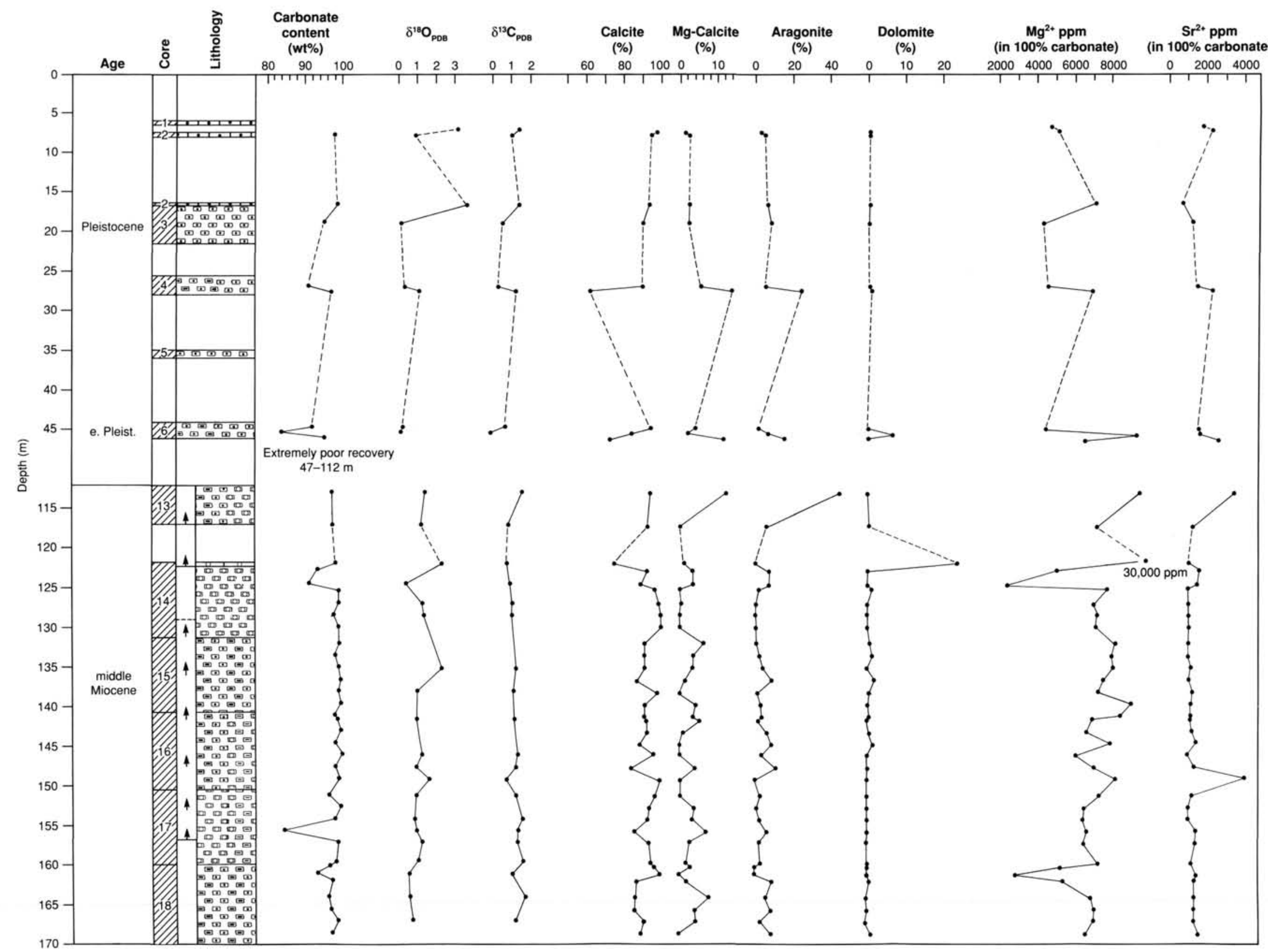

Figure 4. Quantitative mineralogy, carbonate content, geochemistry, and stable isotopes for Hole 626C. Lithologic symbols are those of Palmer et al. (1986, Fig. 8). Recovered core intervals are indicated in core column by diagonal lines. 

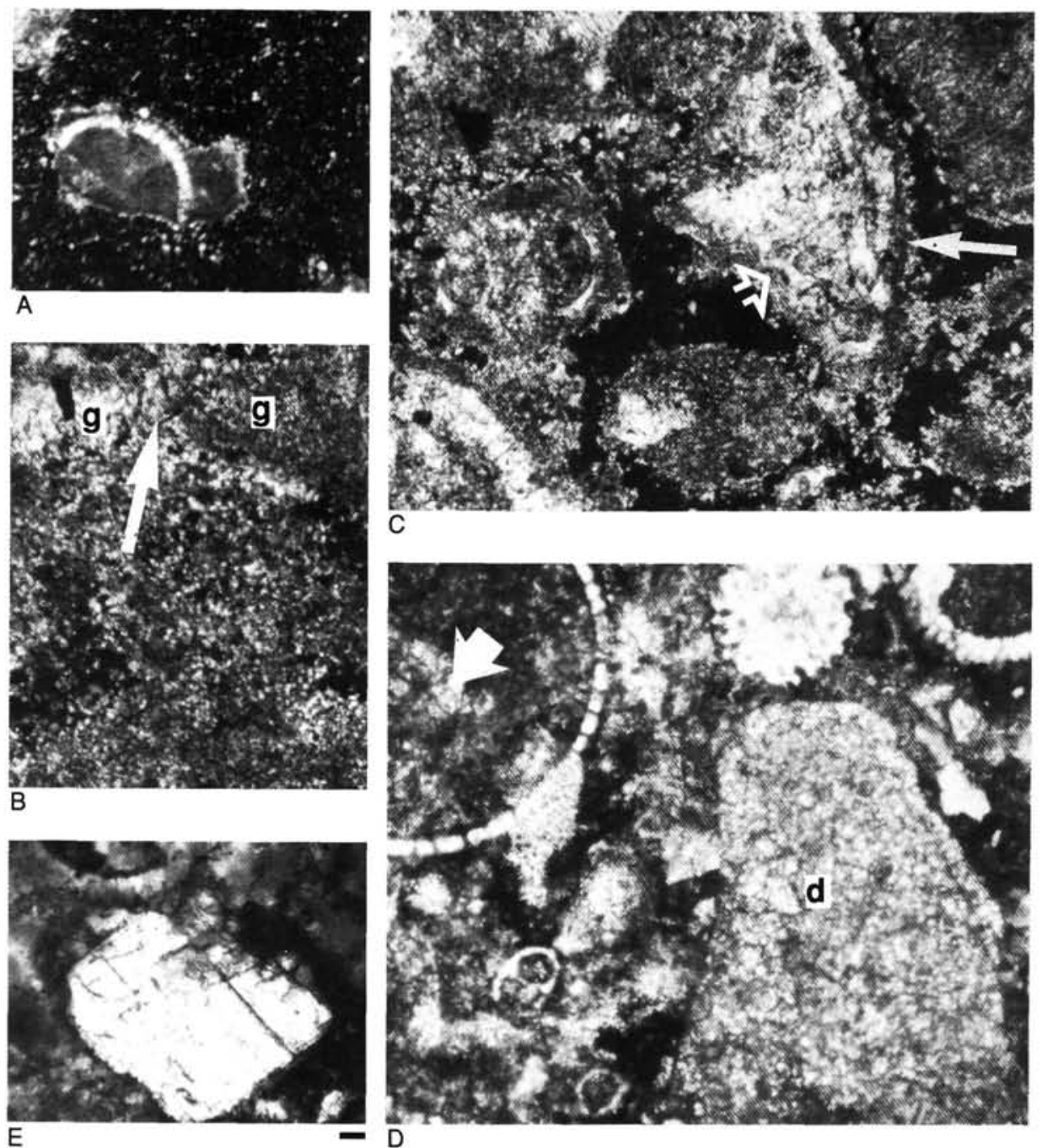

\section{C}

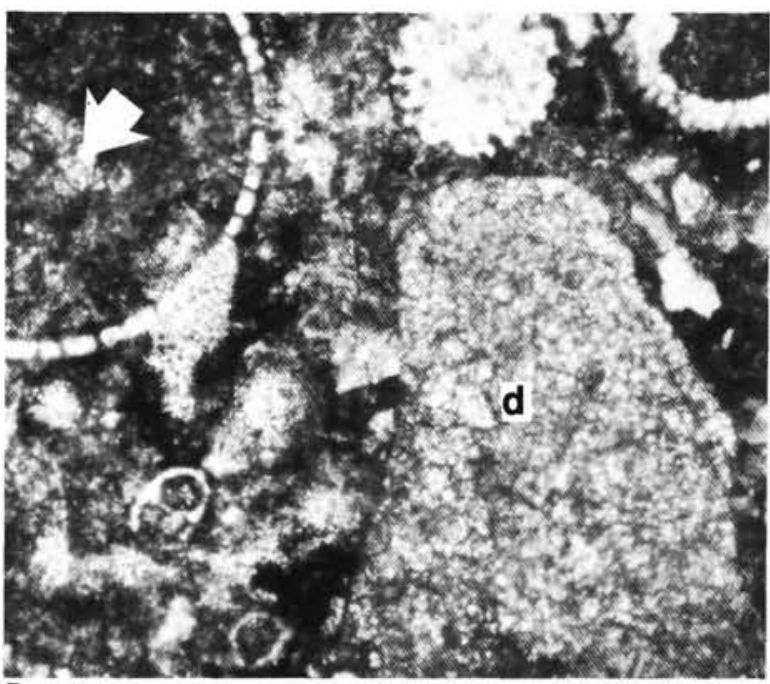

$\mathrm{D}$
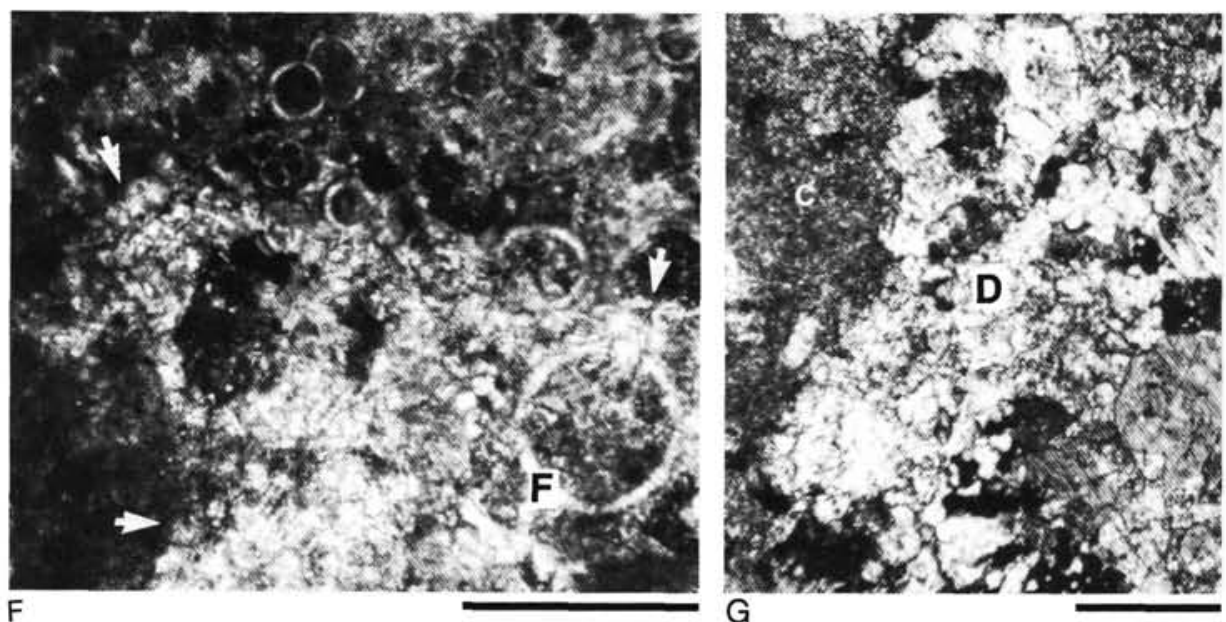

Figure 5. Petrographic characteristics (cross-nicols) of Hole 626C. (A) Deep-water lithoclast of planktonic foraminifer micrite, Sample 101-626C-4X$2,60-62 \mathrm{~cm}$, grain mount. Scale bar is $250 \mu \mathrm{m}$. (B) Microcrystalline calcite (arrow) appearing to act as cement between two diffuse microcrystalline grains $(\mathrm{g})$, Section 101-626C-1X, CC. Scale bar is $100 \mu \mathrm{m}$. (C) Weakly cemented and partially micritized grainstone (Sample 101-626C-14H-4, 64-66 $\mathrm{cm}$ ), with micrite envelope developed on the skeletal grain (solid arrow) and an embayed edge of allochem (open arrow). Scale bar is $100 \mu \mathrm{m}$. (D) Geopetal, microcrystalline dolomite (arrow) and rounded, detrital fragment of microcrystalline dolomite (d) from Sample 101-626C-14H-1, 19-21 $\mathrm{cm}$. Scale bar is $100 \mu \mathrm{m}$. (E) Partially anhedral, but apparently in-situ, dolomite rhombohedron from same sample as D. Scale bar is $100 \mu \mathrm{m}$. (F) Mosaic dolomite, forming part of a vague rhombohedral outline (arrows), has replaced planktonic foraminifers $(F)$ and calcite matrix. From same sample as D; scale bar is $50 \mu \mathrm{m}$. (G) Mosaic dolomite $(d)$ with microcrystalline calcite $(c)$ from same sample as D. Scale bar is $100 \mu \mathrm{m}$. 


\section{Carbonate Content and Mineralogy}

Total carbonate content ranges from a minimum of $75 \%$ to a maximum of $95 \%$ (Fig. 6), with an anomalously low value of $63 \%$ caused by the middle Eocene chert. Overall, total carbonate content displays two, broad, sinusoidal, cyclic waveforms with maxima in the Upper Cretaceous, lower to middle Eocene, and lower Pliocene and with minima in the lower Eocene, upper Miocene, and upper Pleistocene (Fig. 7). Superimposed on these broad, first-order trends, are high-frequency, high-amplitude, second-order variations (Figs. 6 and 7). In the upper $25 \mathrm{~m}$, both first and second order carbonate maxima correspond to absent or lowered aragonite.

Quantitative carbonate mineralogical data indicate that a rapid loss of co-varying $(r=0.89)$ aragonite and high-magnesian calcite occurs with increased calcite in the top $9 \mathrm{~m}$ of Hole 98 (Fig. 6). Magnesian calcite is absent below the unconformity at 9.5 mbsf. Aragonite also decreases to $0 \%$ below the unconformity but reappears in concentrations up to $23 \%$ between 23 and $64 \mathrm{mbsf}$ (Fig. 6.). Calcium-rich dolomite occurs in minor amounts $(<5 \%)$ throughout the upper $64 \mathrm{~m}$ of Hole 98 , with a maximum of $7 \%$ directly below the Pliocene/Pleistocene unconformity at 9.5 mbsf (Fig. 6). Below $64 \mathrm{mbsf}$, calcite is the only carbonate mineral present. Comparison of X-ray diffractograms from the upper $9 \mathrm{~m}$ of Hole 98 suggests a gradual loss with depth of magnesium from high-magnesian calcites (Fig. 8). At depths of 1.0 and $4.5 \mathrm{mbsf}$, the $\mathrm{mol} \% \mathrm{MgCO}_{3}$ of calcite is about $12 \%$ to $14 \%$, indicating a platform-derived source (Heath and Mullins, 1984). However, a gradual shift of the intervening high-magnesian calcite peaks toward lower $2 \theta$, which indicates the removal of magnesium from the crystal lattice (Gomberg and Bonatti, 1970). At 3 and 9 mbsf, high-magnesian calcite neomorphosed to low-magnesian calcite that contains less than $4 \mathrm{~mol}_{\%} \mathrm{MgCO}_{3}$ (Fig. 8).

\section{Geochemistry}

Elemental analyses indicate that both strontium and magnesium concentrations decrease rapidly in the upper $10 \mathrm{~m}$ of Hole 98 (Fig. 6). Below this depth, magnesium continues toward lower values, from about $6000 \mathrm{ppm}$ to a minimum of $1000 \mathrm{ppm}$ at 357 mbsf. Magnesium concentrations continue to decrease with depth because no magnesian calcite occurs below $10 \mathrm{mbsf}$, and no dolomite is present below 58 mbsf (Fig. 6). This decrease may indicate that magnesium continues to be exsolved from low-magnesian calcite.

Between 10 and 64 mbsf, strontium concentrations display a linear increase from about 1000 to $3000 \mathrm{ppm}$, despite aragonite being absent between 10 and 23 mbsf (Fig. 6). Baker et al. (1982) showed that the strontium concentrations of interstitial pore waters in deep-sea carbonates typically increase in the first 200 to $300 \mathrm{~m}$ of burial. The increase of strontium with depth in Hole 98 may indicate that calcite is precipitating in the sediment column in the presence of strontium-rich pore waters. However, part of the increase in strontium simply reflects the occurrence of aragonite between 23 and 64 mbsf. Below 64 mbsf, strontium concentrations gradually decrease to values of less than 1000 $\mathrm{ppm}$ at the bottom of the hole.

Stable oxygen-isotope ratios indicate a rapid enrichment of $\delta^{18} \mathrm{O}$ in the top $8.5 \mathrm{mbsf}$ from -0.5 to $+2.0 \%$ (Fig. 6). About $1.5 \%$ of the variance in oxygen values occurs in the top $2 \mathrm{~m}$. There is an overall depletion of $\delta^{18} \mathrm{O}$ of about $2.5 \%$ with increasing depth that may reflect precipitation in progressively warmer diagenetic environments with increased burial, similar to deep-sea pelagic carbonates (Garrison, 1981). Two intervals of more depleted $\delta^{18} \mathrm{O}$ occur in the upper Miocene section between 15 and 25 mbsf (Fig. 6).
Stable carbon ratios show a rapid depletion of $\delta^{13} \mathrm{C}$ of about $1.5 \%$ in the upper $2 \mathrm{mbsf}$ (Fig. 6). From here to about $60 \mathrm{mbsf}$, $\delta^{13} \mathrm{C}$ values fluctuate little from the $1.0 \%$ value, suggesting that carbon derived from a marine reservoir (Hudson, 1977). From 97 to 357 mbsf, carbon ratios display a subtle decrease to 240 mbsf, followed by an increase (total deviation of about $2.0 \%$ ) that mimics both the total carbonate and $\delta^{18} \mathrm{O}$ curves (Figs. 6 and 7).

\section{Microscopic Characteristics}

Aragonite needles, coccoliths, and planktonic foraminifers are well preserved in the upper $9 \mathrm{~m}$ of Hole 98 . However, the occurrence of micrometer-sized, anhedral to euhedral calcite crystals, coupled with an overall decrease in percentages of metastable aragonite, high-magnesian calcite, and trace elements (Fig. 6 ), suggests that dissolution and reprecipitation occur at these shallow-burial $(<10 \mathrm{~m})$ depths. Dolomite, distributed sporadically in the upper $60 \mathrm{~m}$, occurs as small $(<10 \mu \mathrm{m})$, authigenic, euhedral crystals, indicating an in-situ origin (Fig. 9A) similar to that reported by Mullins et al. (1985b). Dolomite is most abundant directly beneath the Pliocene/Pleistocene disconformity.

At 24 mbsf, upper Miocene chalks contain numerous vugs (Fig. 9B) that appear to have primary porosity rather than dissolution features, although this is uncertain (see Site 630). Wellpreserved aragonite needles also occur at this sub-bottom depth coincidentally with elevated aragonite content, as defined by X-ray diffraction (Fig. 6).

Between 102 and 136 mbsf, siliceous sponge spicules and their molds are common. Below $102 \mathrm{~m}$, calcite overgrowths on coccoliths increase significantly, along with interskeletal, microcrystalline, calcitic cement (Fig. 9C). Hole 98 bottoms (at $357 \mathrm{mbsf}$ ) in indurated Upper Cretaceous chalks that consist of resistant coccoliths engulfed by anhedral calcite crystals (Fig. 9D); however, interstitial porosity has not yet been obliterated completely.

\section{Site Summary}

Mineralogical and geochemical data (Fig. 6) indicate that the upper part of the sediment column at Site 98 is derived from adjacent bank tops and reflects a primary signal, as found elsewhere in similar sediments from the Bahamas (Kier and Pilkey, 1971; Droxler et al., 1983; Boardman and Neumann, 1984; Boardman et al., 1986). However, correlation of high carbonate content with lowered aragonite is the opposite of what was found previously in the Bahamas; that is, carbonate content and aragonite are proportional, with high percentages deposited during interglacial periods and bank-top flooding. The first and second order carbonate variation from Hole 98 may represent varying intensities of current scouring related to sea level fluctuations. For example, higher velocity currents during low sea level stands (decreased influx of aragonite) might entrain insoluble residue (clay and organic matter), resulting in raised carbonate concentrations but lowered aragonite contents.

However, any primary signal within the upper $10 \mathrm{~m}$ of Hole 98 is overprinted by rapid diagenesis, transforming aragonite and high-magnesian calcites to calcite, with concomitant depletion of magnesium, strontium, and $\delta^{13} \mathrm{C}$ ratios and enrichment of $\delta^{18} \mathrm{O}$ values. This indicates diagenesis proceeds by rapid equilibration with deep marine-derived pore fluids. Magnesian calcites exsolve to calcite and are not present below 9 mbsf, whereas aragonite undergoes dissolution and reprecipitation and persists to about 64 mbsf. The occurrence of aragonite between 23 and 64 mbsf is not consistent with progressive stabilization with burial and may represent either a preserved influx signal or an unusual diagenetic product. The concentration of dolomite immedi- 


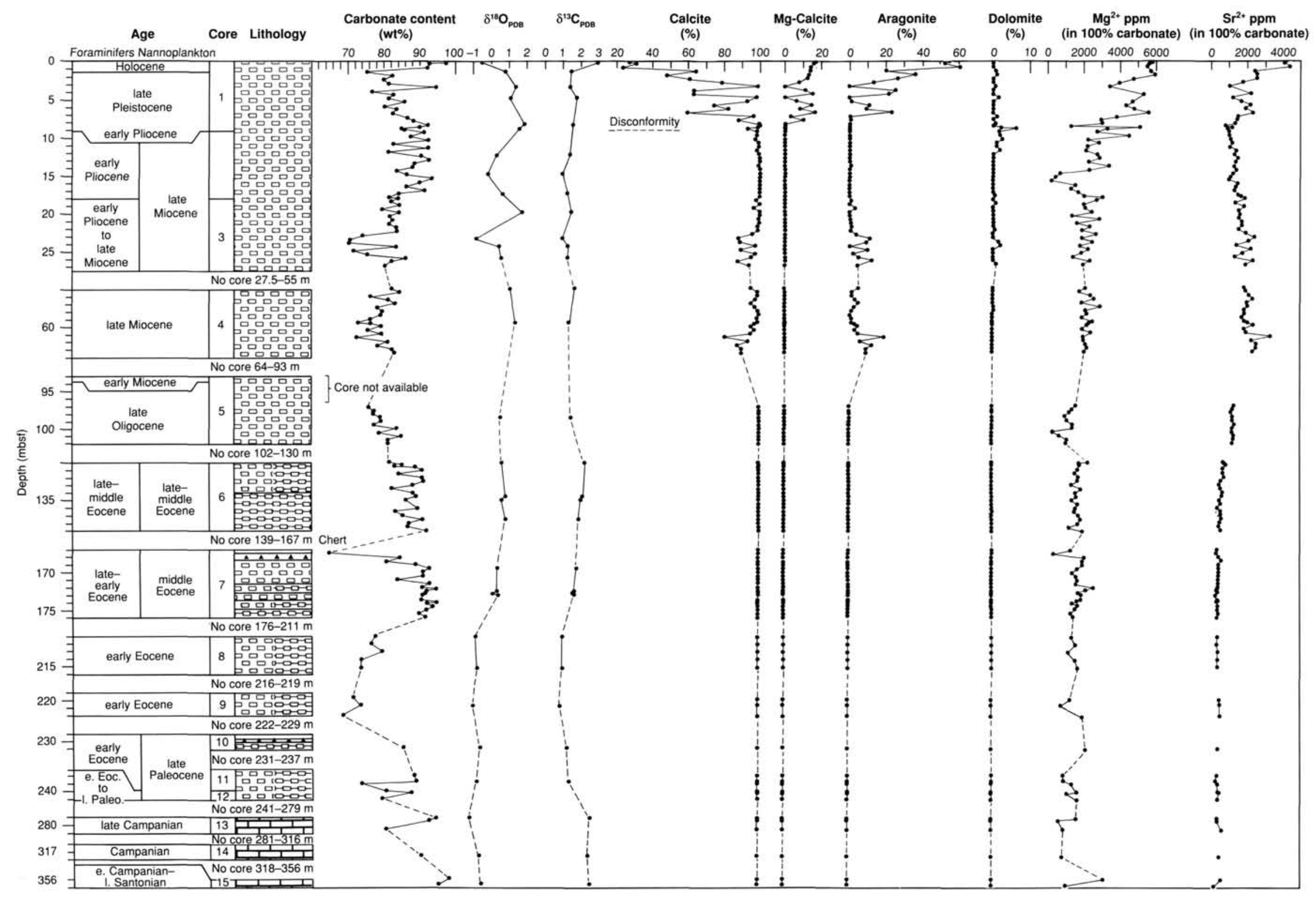

Figure 6. Quantitative mineralogy, carbonate content, geochemistry, and stable isotopes for DSDP Hole 98. Core descriptions (see Fig. 2) are taken from Hollister, Ewing, et al. (1972). Lithologic symbols are those of Palmer et al. (1986, Fig. 8). 


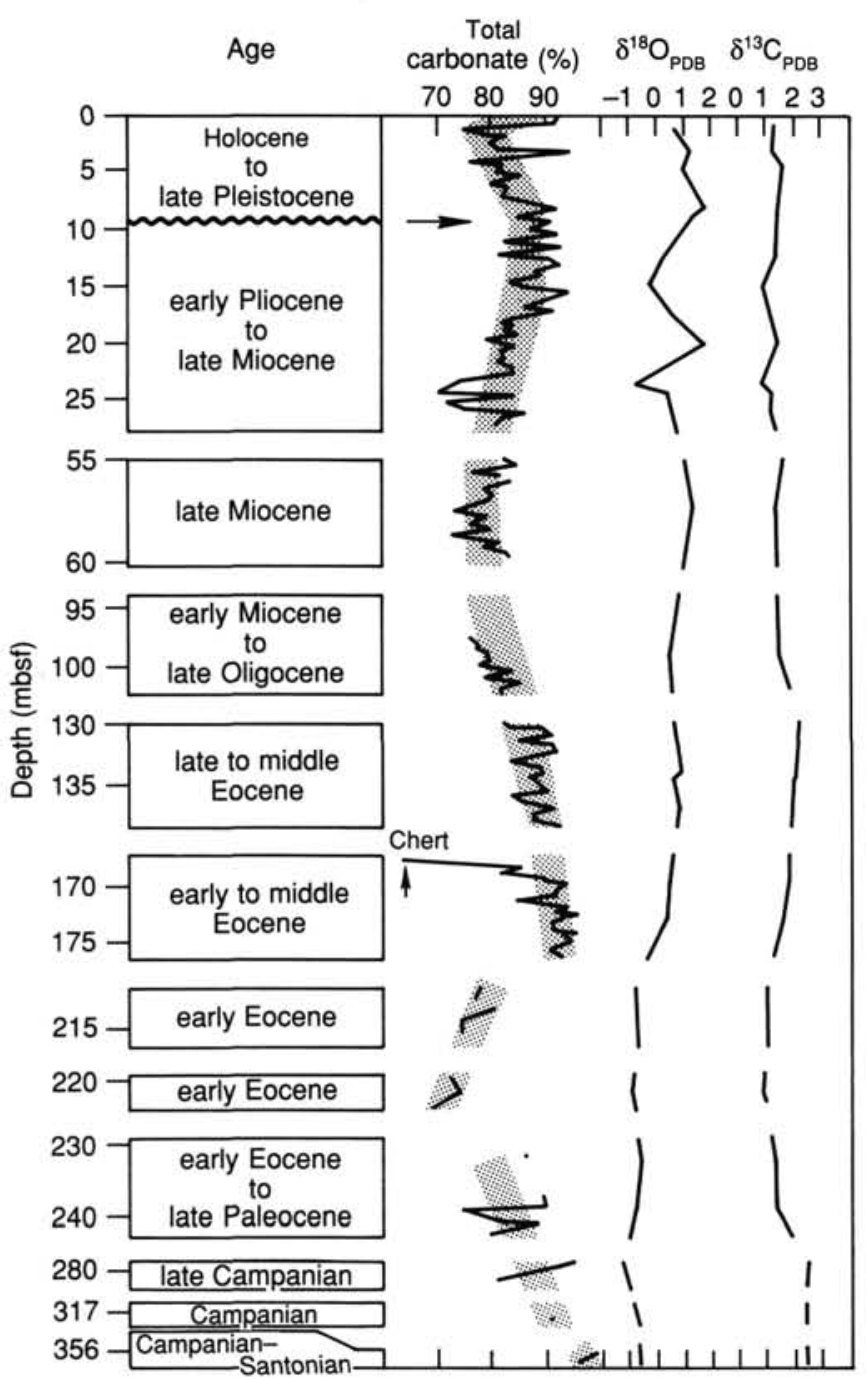

Figure 7. Apparent secular variation of total carbonate content for DSDP Hole 98, plotted along with stable-isotope data. The latter may have covaried with carbonate content prior to the Miocene. Higher frequency variation of carbonate content is superimposed on a general (stippled) trend. Note that the vertical scale is nonlinear. The noncored intervals are not represented. Ages for each cored interval are indicated.

ately below the disconformity at 9 mbsf may have resulted from circulation of seawater through the uppermost sediments during prolonged exposure.

Below 64 mbsf, carbonate sediments are essentially $100 \% \mathrm{cal}-$ cite and thus have a reduced diagenetic potential. Continued loss of strontium and magnesium and depletion of $\delta^{18} \mathrm{O}$ suggest slower, longer-term diagenetic alterations with increased burial to at least 357 mbsf.

\section{Hole 630A, Northern Little Bahama Bank}

\section{Lithology}

Site 630 is located in $807 \mathrm{~m}$ of water on an interfluve along the upper bypass slope of northern Little Bahama Bank (Mullins et al., 1984; Austin, Schlager, et al., 1986; Fig. 1). Core recovery was high $(88 \%)$, which along with moderate sedimentation rates (28-62 m/m.y.; Austin, Schlager, et al., 1986) allowed us to sample in detail for our diagenetic studies.

The upper $150 \mathrm{~m}$ (Fig. 2) of sediment in Hole 630A is dominated by periplatform ooze $(\sim 90 \%)$ having minor turbidites

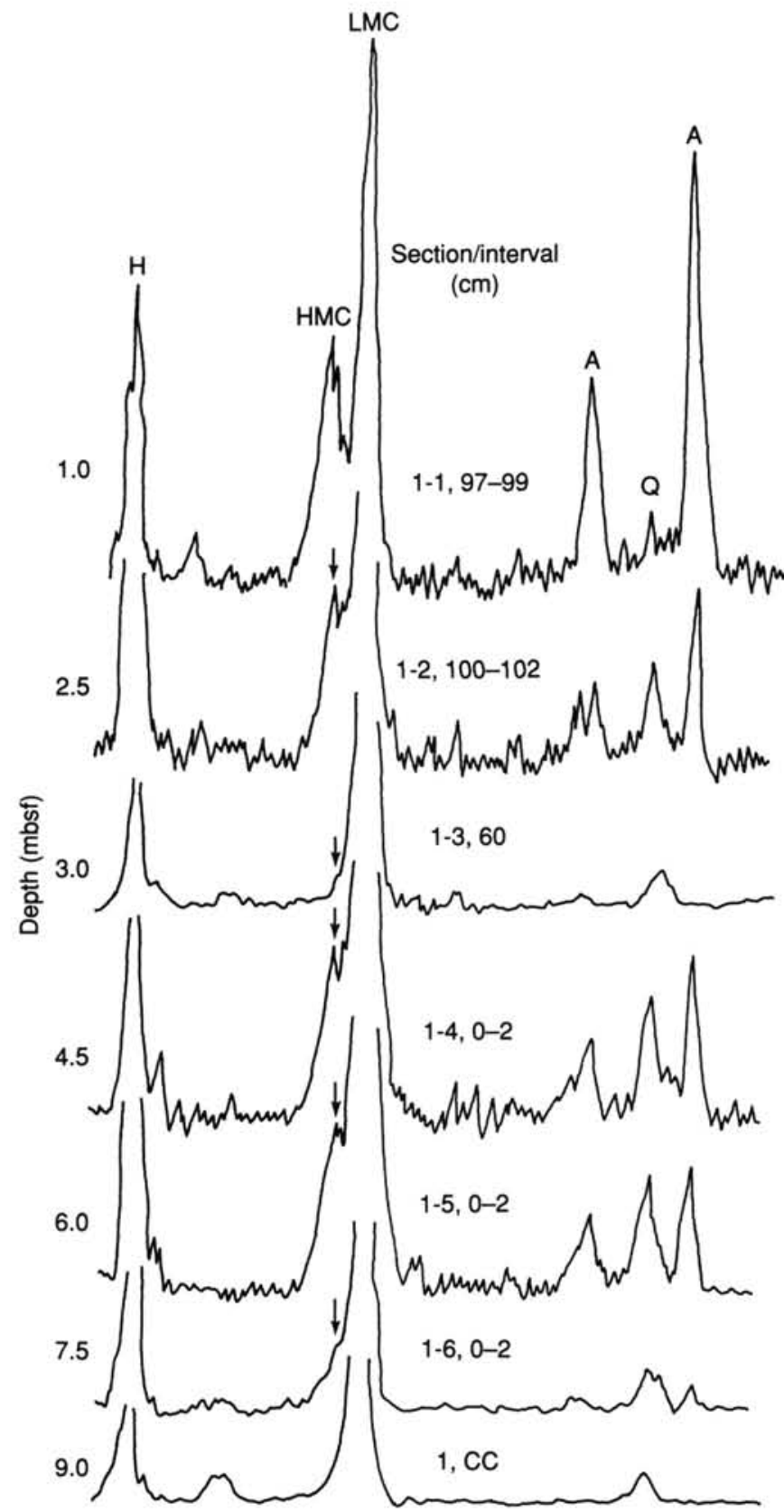

Figure 8. Variation in $\mathrm{MgCO}_{3}$ content in DSDP Hole 98 in the upper 10 $\mathrm{m}$ shows a shift of at least $8 \%$ to $10 \%$, as indicated by a shift in highmagnesian calcite (HMC) toward low-magnesian calcite ( $L M C) . \mathrm{MgCO}_{3}$ content decreases to within that of $L M C$ by 3 mbsf. A second shift begins at $4.5 \mathrm{mbsf}$ and extends down to 9 mbsf. Peak $\mathrm{MgCO}_{3}$ content at $4.5 \mathrm{mbsf}$ may be slightly less than that found at the sediment/water interface. Percentage of aragonite also fluctuates over these same intervals. Depths are given on left, and core sections and intervals from DSDP Hole 98 are indicated. $H=$ halite; $A=$ aragonite; $Q=$ quartz.

$(\sim 10 \%)$. Evidence for incipient lithification occurs as shallow as 30-35 mbsf, based on core descriptions (Austin, Schlager, et al., 1986). An unconformity separating upper Pliocene and Pleistocene sediments occurs at about 12 mbsf. Between 150 and 200 mbsf, an increase in turbidites (to $40 \%$ ) probably represents the Neogene seaward progradation of upper-slope facies over older, lower-slope facies north of Little Bahama Bank (Austin, Schlager, et al., 1986). 

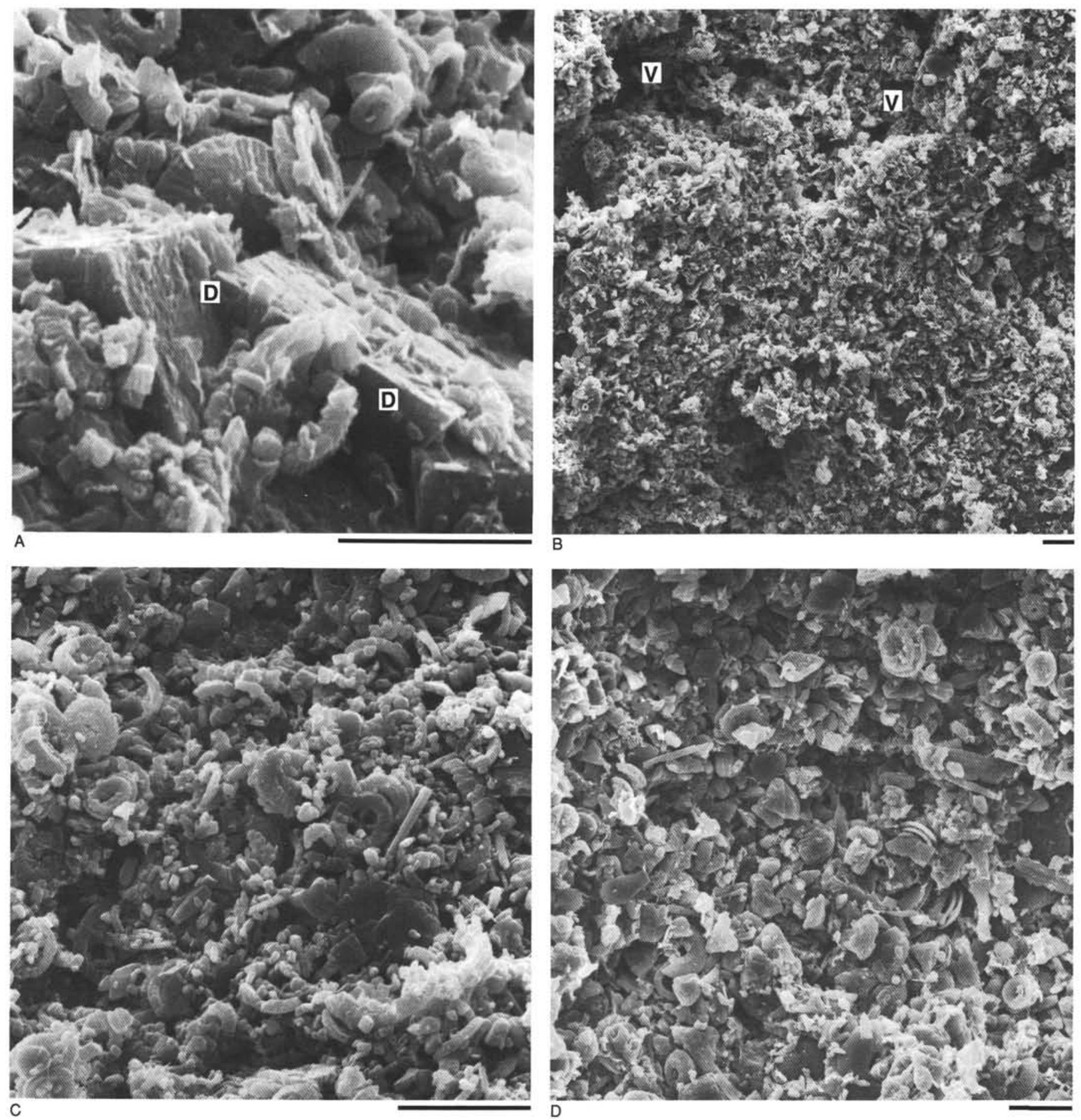

Figure 9. SEM photomicrographs of DSDP Hole 98 samples. (A) Dolomite rhombohedra $(D)$ immediately below the Pleistocene/Pliocene disconformity (Sample $98-2 \mathrm{H}-1,5-7 \mathrm{~cm} ; 9.05 \mathrm{mbsf}$ ). Scale bar is $5 \mu \mathrm{m}$. (B) Overview of sediment at $24 \mathrm{mbsf}$ (Sample $98-3 \mathrm{H}-5,0-2 \mathrm{~cm}$; lower Pliocene) showing irregular, vuggy $(V)$ nature of the sediment. Scale bar is $10 \mu \mathrm{m}$. (C) Fragmented, overgrown coccoliths in well-compacted chalk having anhedral to euhedral microcrystalline calcite and calcite fragments of indeterminate origin (Sample 98-6H-5, 49-51 cm, $136.5 \mathrm{mbsf}$ ). Scale bar is $10 \mu \mathrm{m}$. (D) Abundant microcrystalline calcite, overgrown coccoliths, and skeletal fragments (Sample 98-15R-1, 131-133 cm; 356.8 mbsf, Upper Cretaceous). Scale bar is $10 \mu \mathrm{m}$.

\section{Carbonate Content and Mineralogy}

Total carbonate content throughout Hole 630 is high $(95 \%)$ and varies little ( $<8 \%$; Fig. 10). The only significant departure is at $19 \mathrm{mbsf}$, where carbonate content decreases to a minimum value of $75 \%$. However, this subsample was recovered from a dark to light gray, unlithified, bioturbated mudstone (Fig. 11) having a sharp base that is obviously allochthonous.
Unlike total carbonate content, the carbonate mineralogy in Hole 630A fluctuates greatly (Fig. 10), particularly in the upper $10 \mathrm{~m}$ of the hole. Surface sediments are rich in metastable components; aragonite content ranges from $0 \%$ to $60 \%$, co-varying with high-magnesian calcite $(r=0.83)$ that ranges from $0 \%$ to $25 \%$ (Fig. 10). Calcite also displays large percentage swings, ranging from $65 \%$ to $100 \%$, in response to cyclic changes in meta- 
stable components. Dolomite is common in the upper $10 \mathrm{~m}$, particularly where aragonite is absent, and reaches a maximum abundance of about $10 \%$ (Fig. 10).

SEM observations indicate that dolomite is authigenic and, together with rounded aragonite needles (indicating partial dissolution), suggest that these high-amplitude cycles are partly diagenetic, and probably overprint a high-frequency depositional signal (cf. Droxler et al., 1983). However, such abrupt changes and range variations in carbonate mineralogy have never before been described from the northern Bahamas at such shallowburial depths.

Below 10 mbsf at Site 630 , the aragonite content gradually decreases to $0 \%$ at 92 mbsf (Fig. 10). This decrease partly results from primary influx because the northern margin of Little Bahama Bank once was farther south than it is today (Austin, Schlager, et al., 1986). Between 92 and 237 mbsf, aragonite occurs sporadically in trace amounts only. However, near the bottom of Hole $630 \mathrm{~A}$, aragonite reappears in concentrations up to $12 \%$. This reappearance in sediments of late Miocene age also occurs in Hole 98 (compare Fig. 6 with Fig. 10) and suggests a common depositional, preservational, or diagenetic event.

High-magnesian calcite percentages decrease rapidly over the upper $2 \mathrm{~m}$ in Hole $630 \mathrm{~A}$ (from $25 \%$ to $8 \%$ ). Beneath this section, magnesian calcite occurs in relatively low amounts (trace to $10 \%$ ). Because bank-derived, high-magnesian calcite is more soluble than aragonite in the deep-water regions of the Bahamas (Droxler et al., in press), we interpret the continuation of highmagnesian calcite throughout the core as a chemical precipitate, either as overgrowths on skeletal material or as a cement. This is compatible with previous work in the Bahamas region, which found that submarine cements occurring in water depths greater than $1000 \mathrm{~m}$ are typically low-magnesian calcite, whereas above this depth high-magnesian calcite dominates (Schlager and James, 1978).

In the upper $92 \mathrm{~m}$, dolomite may be a precipitate after aragonite dissolution, which is consistent with previous findings for authigenic dolomite in the Bahamas (Mullins et al., 1985b). Dolomite occurs in low amounts in sediment of late Miocene age, between 130 and 180 mbsf (Fig. 10), where aragonite decreases to trace amounts.

\section{Geochemistry}

Strontium concentrations decrease precipitously in the upper $2 \mathrm{~m}$ of Hole $630 \mathrm{~A}$, from 6200 to about $1000 \mathrm{ppm}$, indicating rapid diagenesis (Fig. 10). Between 2 and $12 \mathrm{mbsf}$, strontium shows high-amplitude swings between about 1000 and $3500 \mathrm{ppm}$ along with carbonate mineral fluctuations, particularly aragonite content. From 12 to $92 \mathrm{mbsf}$, strontium values gradually decline from about 3800 to 1000 ppm (Fig. 10). Below $92 \mathrm{mbsf}$, strontium concentrations remain relatively constant at about 1000 ppm, suggesting that the rate of burial diagenesis has decreased significantly.

Magnesium concentrations range from about 6000 to 12,000 ppm (Fig. 10) in the upper $10 \mathrm{~m}$ of the hole. Below $12 \mathrm{mbsf}$, magnesium content continues to vary widely, along with dolomite occurrences, to a depth of about 200 mbsf. Near the base of the hole, magnesium concentrations are reduced to a minimum value of about $5000 \mathrm{ppm}$ (Fig. 10). Such high variability in magnesium content throughout Hole 630A contrasts sharply with the strontium curve, which seems to indicate nearly complete shallow-burial diagenesis at 92 mbsf.

Stable carbon-isotope ratios undergo an abrupt depletion of $\delta^{13} \mathrm{C}$ (from +3.2 to $1.3 \%$ ) in the top $3 \mathrm{~m}$ of Hole $630 \mathrm{~A}$ (Fig. 10), similar to the depletion seen at DSDP Hole 98 (Fig. 6). However, across a disconformity at $12 \mathrm{mbsf}, \delta^{13} \mathrm{C}$ values increase to $+2.4 \%$. Between 12 and 170 mbsf there is a gradual $(\sim 0.01 \% 0 / \mathrm{m})$ depletion of $\delta^{13} \mathrm{C}$ from $+2.4 \%$ to $+1.0 \%$. An enrichment of about $1 \%$ coincides with a sharp increase in highmagnesian calcite content and the disappearance of aragonite at 92 mbsf (Fig. 10). Below $170 \mathrm{~m}$, there is a gradual increase in $\delta^{13} \mathrm{C}$ values from $+1 \%$ to greater than $+3 \%_{0}$ at the base of the hole in sediments of late Miocene age.

Stable oxygen ratios display a slight increase in the upper $3 \mathrm{~m}$ +1.4 to $+2.8 \%$, further indicating rapid diagenetic alteration in deep, cold, marine waters (Fig. 10). Below $3 \mathrm{~m}$, however, the downhole trend remains relatively uniform, bracketing $+2.0 \%$. An anomalous departure from this trend (depletion of about $2 \%$ ) occurs at 19 mbsf, along with the presence of a dark, unlithified dolomitic mudstone with a maximum magnesium content of 19,535 ppm (Fig. 10).

\section{Microscopic Characteristics}

The upper $10 \mathrm{~m}$ of Hole $630 \mathrm{~A}$ is characterized by abrupt, high-amplitude changes in carbonate mineralogy (Fig. 10). SEM observations indicate that aragonite-rich intervals contain abundant, well-preserved needles and blades of aragonite and highmagnesian calcite (Fig. 12A). In aragonite-poor sections, needles have poor preservation, and there is a relative increase in the abundance of calcitic coccoliths (Fig. 12B) as well as in the occurrence of euhedral, authigenic dolomite rhombs with incorporated coccoliths (Fig. 12C). Anhedral to subhedral crystals of magnesian (?) calcite also occur in the aragonite-poor intervals (Figs. 12C and 12D).

Both extent and degree of lithification are variable in the top $70 \mathrm{~m}$ of Hole 630A. Below about $70 \mathrm{~m}$, however, an increase in abundance of microcrystalline high-magnesian(?) calcite occurs both as overgrowths on coccoliths and as interstitial cement. Chalks become more common but are still interbedded with unlithified ooze, which suggests that the decrease in aragonite percentages to $92 \mathrm{~m}$ also is partly a diagenetic trend related to subbottom dissolution. At 111 mbsf, chalks display abundant evidence for dissolution of aragonite in the form of secondary moldic porosity (vugs; Fig. 13A) and partially dissolved aragonitic skeletal grains (Fig. 13B), indicating that at least one episode of lithification occurred, followed by dissolution at greater depths.

\section{Site Summary}

Mineralogy, geochemistry, and isotopic data from Hole 630A indicate that extensive diagenesis occurs rapidly in the upper $10 \mathrm{~m}$ of the sediment column, with diagenetic carbonate in equilibrium with deep, marine-derived pore fluids. Below this depth, more gradual diagenetic transitions occur to $92 \mathrm{mbsf}$, where aragonite "effectively" disappears. Diagenetic alteration is superimposed on the interpreted depositional control of aragonite related to progradation of Little Bahama Bank (Austin, Schlager, et al., 1986). The reoccurrence of minor aragonite in upper Miocene sediment near the base of Hole 630A, however, is inconsistent with simple, gradualistic, burial diagenesis. As interpreted for Hole 98, the presence of aragonite at depth may in part be a result of preserved (or modified) primary input. Below $92 \mathrm{~m}$, only minor diagenetic changes occur because of the reduction of diagenetic potential at shallower depths.

The distribution of high-magnesian calcite below the 92 mbsf aragonite datum suggests that it occurs as a diagenetic precipitate (cement). Dolomite, which is common throughout the hole, appears to be the result of exsolution of magnesium from magnesian calcites and the dissolution of aragonite. Additional magnesium influx from seawater also may occur (Saller, 1984; Land, 1985; Mullins et al., 1985a). Isotopic ratios and their uniform downhole trend support our interpretation that all diagenetic transformations in sub-bottom depths occurred in an open, deep-marine diagenetic environment. 


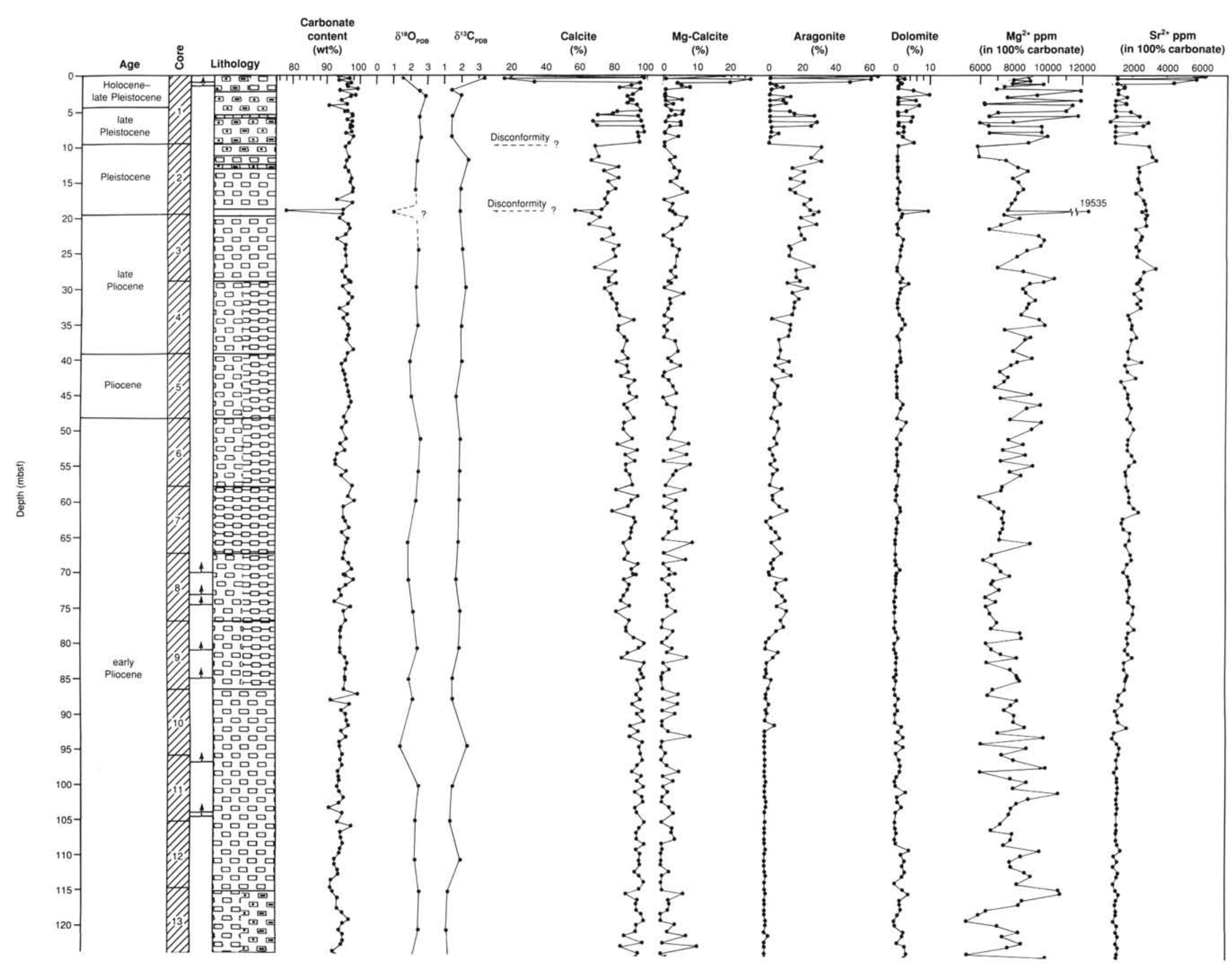




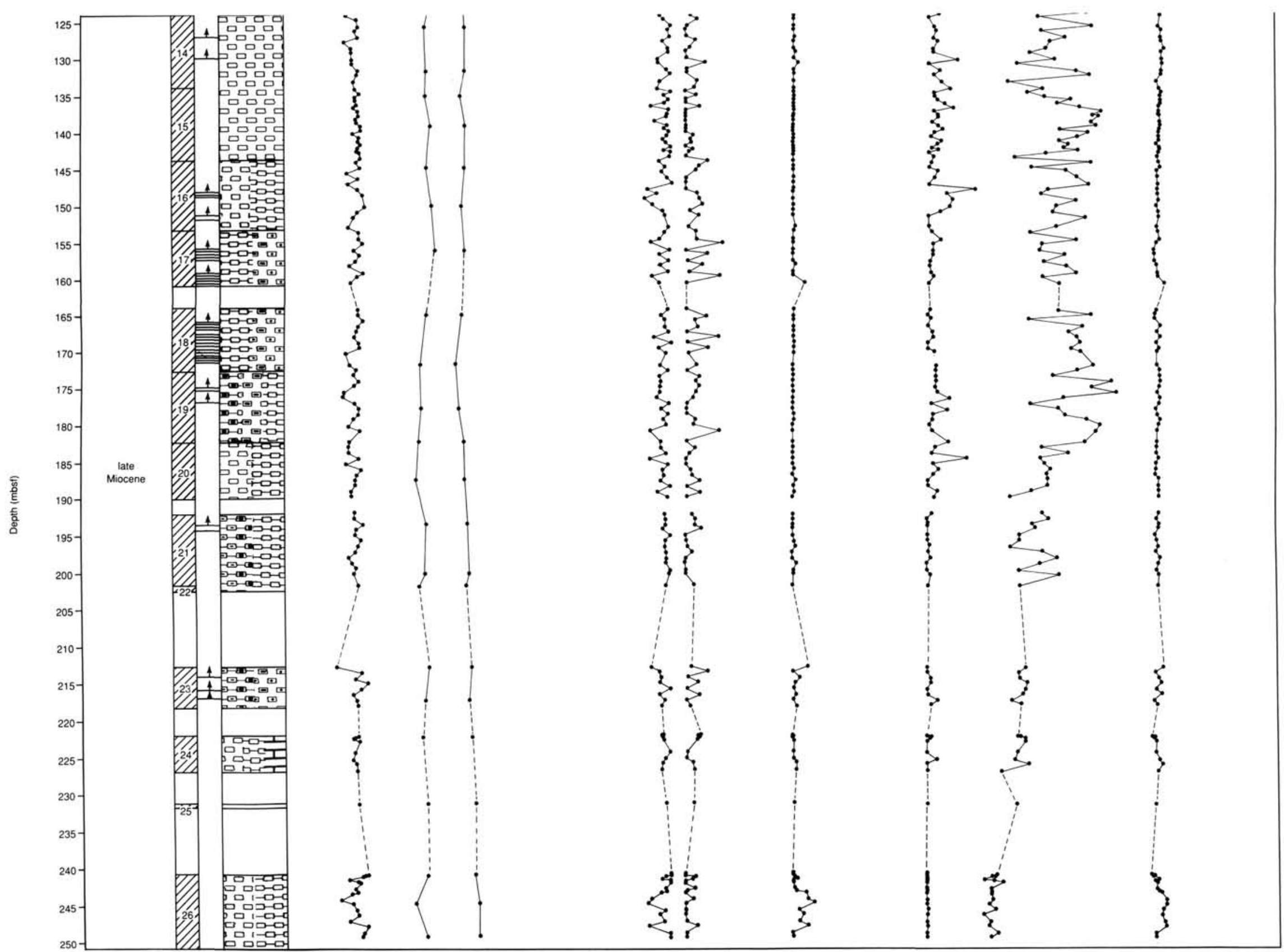
logic symbols are those of Palmer et al. (1986, Fig. 8). 


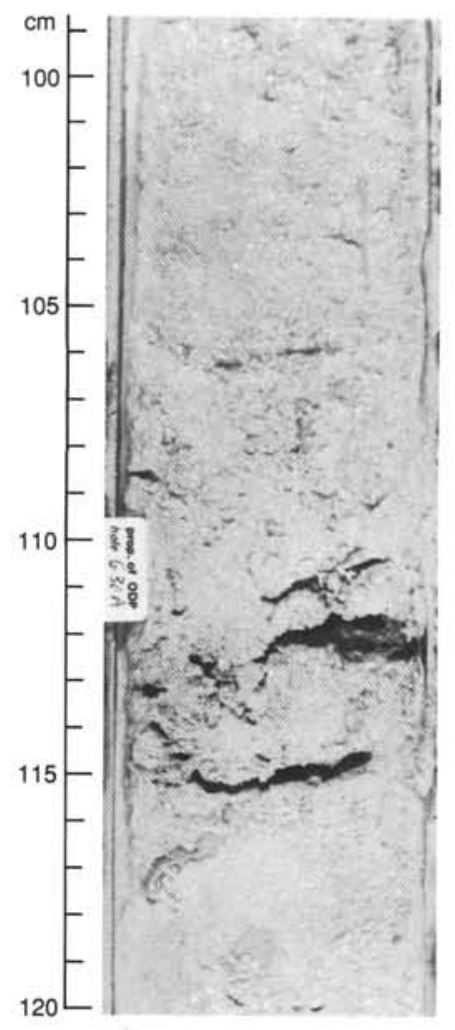

A

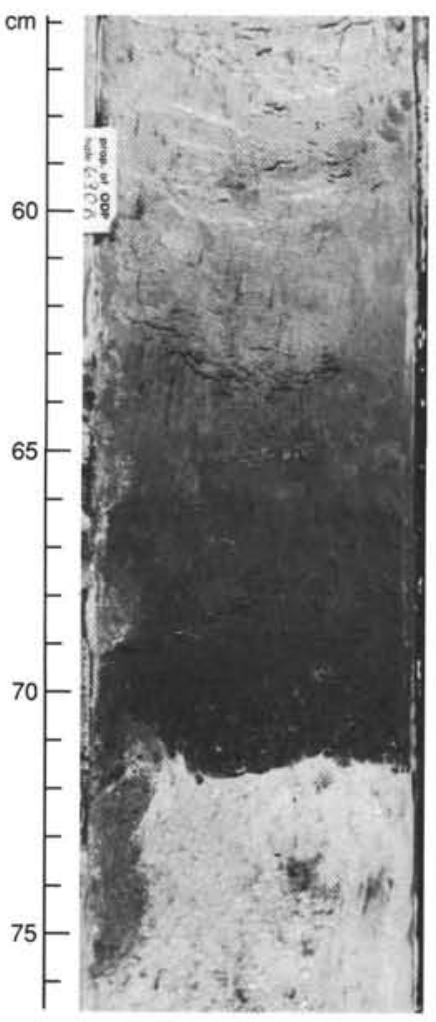

B
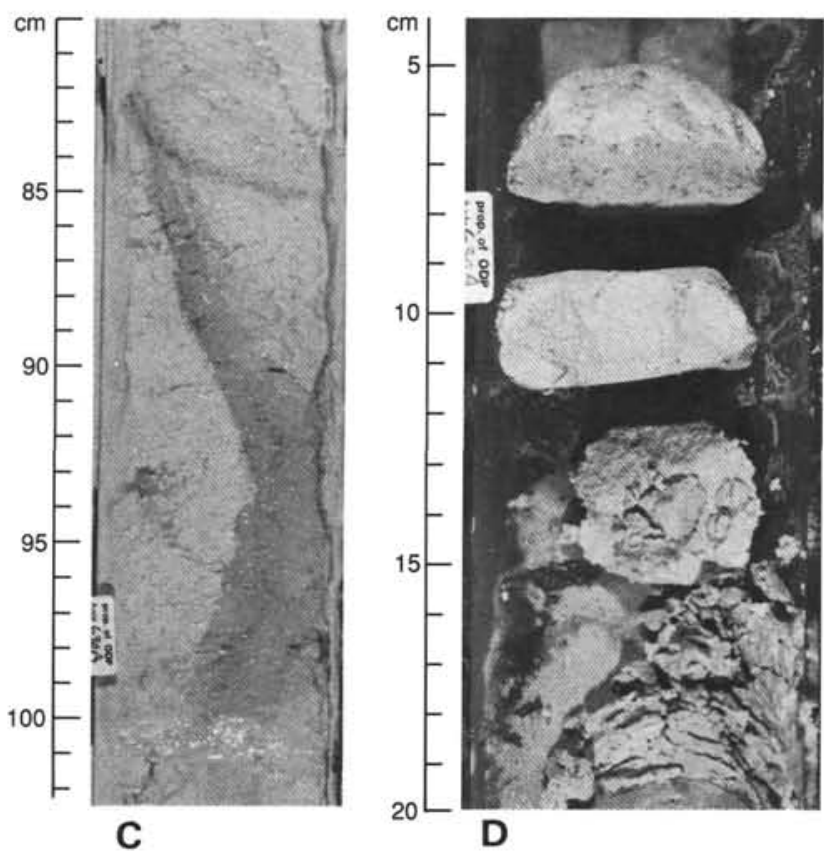

Figure 11. Selected photographs of Hole 630A cores. (A) Sample 101-630A-1H-1, 100-120 cm; ooze and thin unlithified packstones. (B) Sample 101630B-3H-3, 56-76 cm, unlithified mudstone overlying ooze; a similar unit occurs at approximately 19 mbsf in Hole 630A. (C) Sample 101-630A-6H$4,80-100 \mathrm{~cm}$, showing diagenetic purple banding (sulfide?). (D) Sample 101-630A-26X-1, 0-20 cm, chalk.

\section{Hole 631A, Exuma Sound}

\section{Lithology}

Site 631 occurs at a water depth of $1081 \mathrm{~m}$, located on a steep, upper bypass slope in southern Exuma Sound, a closed seaway (Fig. 1). Cores (recovered to a depth of $244 \mathrm{mbsf}$ ) consist entirely of upper Miocene-Holocene periplatform ooze. An inferred hiatus is present at about 25 mbsf in sediments of late Pliocene age (Fig. 2) (Austin, Schlager, et al., 1986). Accumulation rates are high, ranging up to $90+\mathrm{m} / \mathrm{m} . \mathrm{y}$. and produce an expanded section ideal for burial diagenesis studies. Excellent core recovery was possible only in the upper $185 \mathrm{~m}$ (Fig. 2). Because of differential core recovery we sampled only the upper $185 \mathrm{~m}$ of Hole 631A. Evidence of lithification, based on shipboard data, occurs at depths as shallow as $10 \mathrm{mbsf}$, where alternating ooze and chalk occur (Austin, Schlager, et al., 1986). Well-indurated carbonate mudstone (i.e., limestone) first appears between 177 and 185 mbsf subsurface (Fig. 14).

\section{Carbonate Content and Mineralogy}

Total calcium carbonate content values are uniformly high (Fig. 15). Most values fall between $94 \%$ and $98 \%$, with rare deviations of only a few percent and a minimum value of $86 \%$. Carbonate mineral trends in this area are strikingly different from those at any of the three sites described above. The most obvious difference is that both high-magnesian calcite and aragonite persist throughout the core, with a single exception at about 20 mbsf, where the sediments are $100 \%$ calcite (Fig. 15). Abrupt, "step-wise" changes in carbonate mineralogy also occur at about 10 and 85 mbsf (Fig. 15), allowing definition of three mineralogic subdivisions.
The first zone ( $0-10 \mathrm{mbsf})$ is characterized by relatively high proportions of high-magnesian calcite (maximum $32 \%$ ) and aragonite (maximum $72 \%$ ). However, high-amplitude variations in calcite (up to $65 \%$ ) are coincidental with enriched oxygen-isotope ratios and lowered aragonite percentages, suggesting diagenetic transformation over narrow intervals by dissolution of aragonite and precipitation of calcite in equilibrium with deep, marine-derived pore fluids.

The second zone extends between 10 and $85 \mathrm{mbsf}$ and is characterized by reduced percentages of high-magnesian calcite $(\sim 20 \%)$ as well as aragonite $(\sim 40 \%)$ and, consequently, relatively high concentrations of calcite. Superimposed on this zone are high-frequency, moderate-amplitude variations of all three major carbonate minerals. Some fluctuations contain increased percentages of calcite along with enriched oxygen-isotope ratios and lowered aragonite content, suggesting diagenetic alteration over narrow intervals.

The top of the third zone is at $85 \mathrm{mbsf}$, where a relative increase in both high-magnesian calcite and aragonite occurs along with a decrease in calcite content. Between 85 and at least 185 mbsf, high-magnesian calcite content decreases from $25 \%$ to $5 \%$. Aragonite percentages also decrease from $60 \%$ to $40 \%$.

Dolomite occurs only as rare trace quantities over the upper $75 \mathrm{mbsf}$ in Hole 631A (Fig. 15). However, below this depth dolomite with a maximum value of $15 \%$ was found in most samples analyzed.

\section{Geochemistry}

Concentrations of strontium and magnesium can also be subdivided into three major zones, parallel with mineralogical trends (Fig. 15). Strontium values range from a maximum $7800 \mathrm{ppm}$ at 

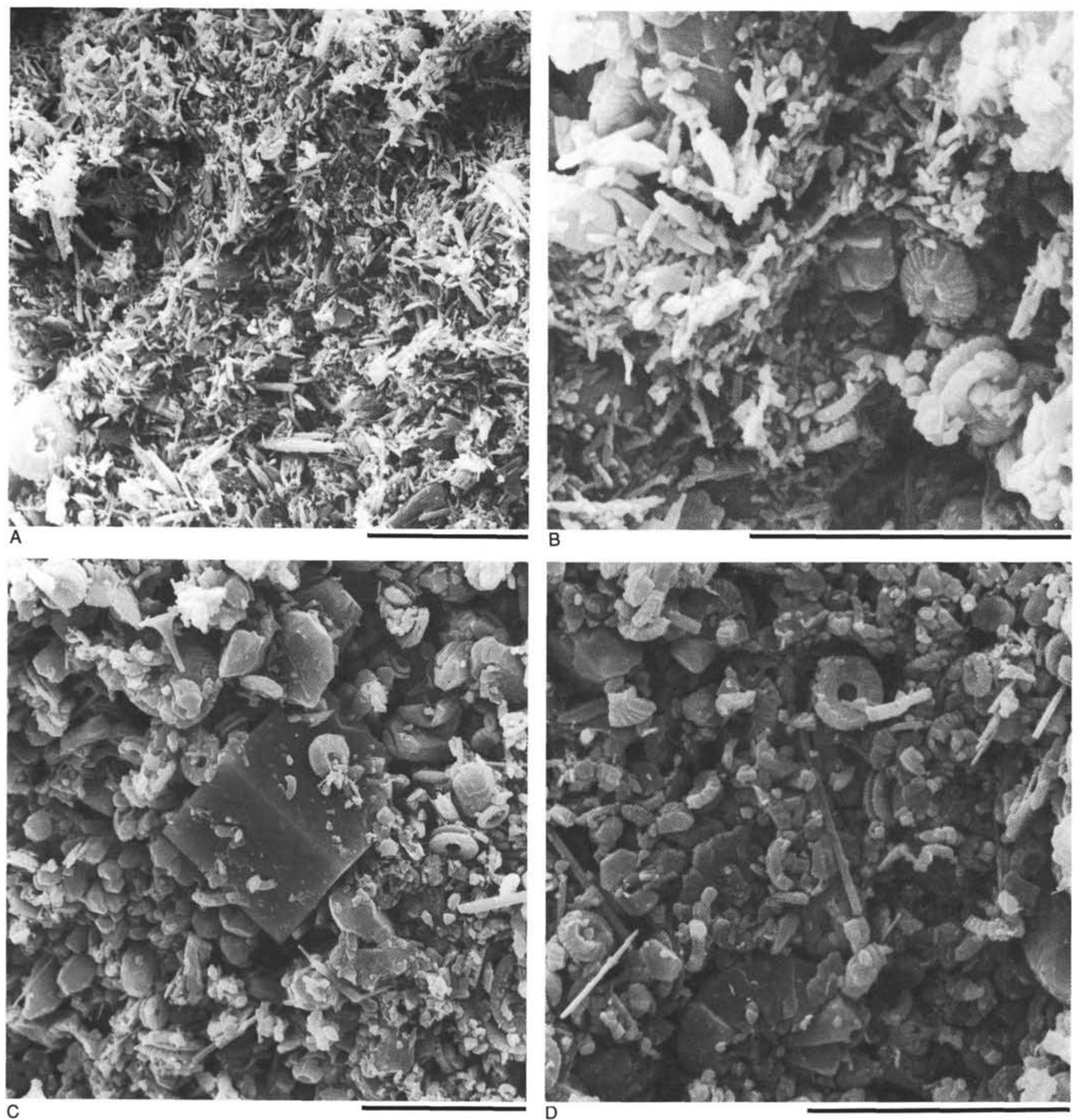

Figure 12. SEM photomicrographs of Hole 630A cores. Scale bars are $10 \mu \mathrm{m}$. (A) Well-preserved aragonite needles in aragonite-rich sediment (Sample 101-630A-1H-1, 49-51 cm; $1.5 \mathrm{mbsf}$ ). (B) Embayed, rounded, and clotted aragonite needles of poor preservation in aragonite-poor sediment (Sample 101-630A-1H-2, 108-110 cm; 2.7 mbsf). Some coccoliths display slight overgrowths. (C) Example of authigenic dolomite found in Hole 630A, in aragonite-poor sediment (Sample 101-630A-1H-2, 108-110 cm; $2.7 \mathrm{mbsf}$ ). (D) Example of abundant, fragmented, and overgrown coccoliths in upper $5 \mathrm{~m}$ of hole (Sample 101-630A-1H-2, 108-110 cm; $2.7 \mathrm{mbsf}$ ).

the top of Hole $631 \mathrm{~A}$ to a minimum of about $1000 \mathrm{ppm}$ at 32 mbsf, which indicates rapid diagenesis. Strontium concentrations decrease abruptly from their maximum value at the seafloor to about $3000 \mathrm{ppm}$ in the first $10 \mathrm{~m}$ of core (Fig. 15), where an abrupt, step-wise decrease occurs at the base of zone 1. Throughout zone 2 , strontium values show considerable variance (up to $2000 \mathrm{ppm}$ ) superimposed on a slight overall increase
(Fig. 15). At 85 mbsf (top of zone 3), strontium concentrations increase abruptly from about 3500 to $5500 \mathrm{ppm}$, indicating preservation of a primary influx signal related to considerable influx of bank-derived, high-strontium aragonite. At 185 mbsf, strontium values are about $5000 \mathrm{ppm}$, which is in sharp contrast to values at similar sub-bottom depths at Sites 98,626, and 630, where strontium concentrations are less than $2000 \mathrm{ppm}$. Over- 

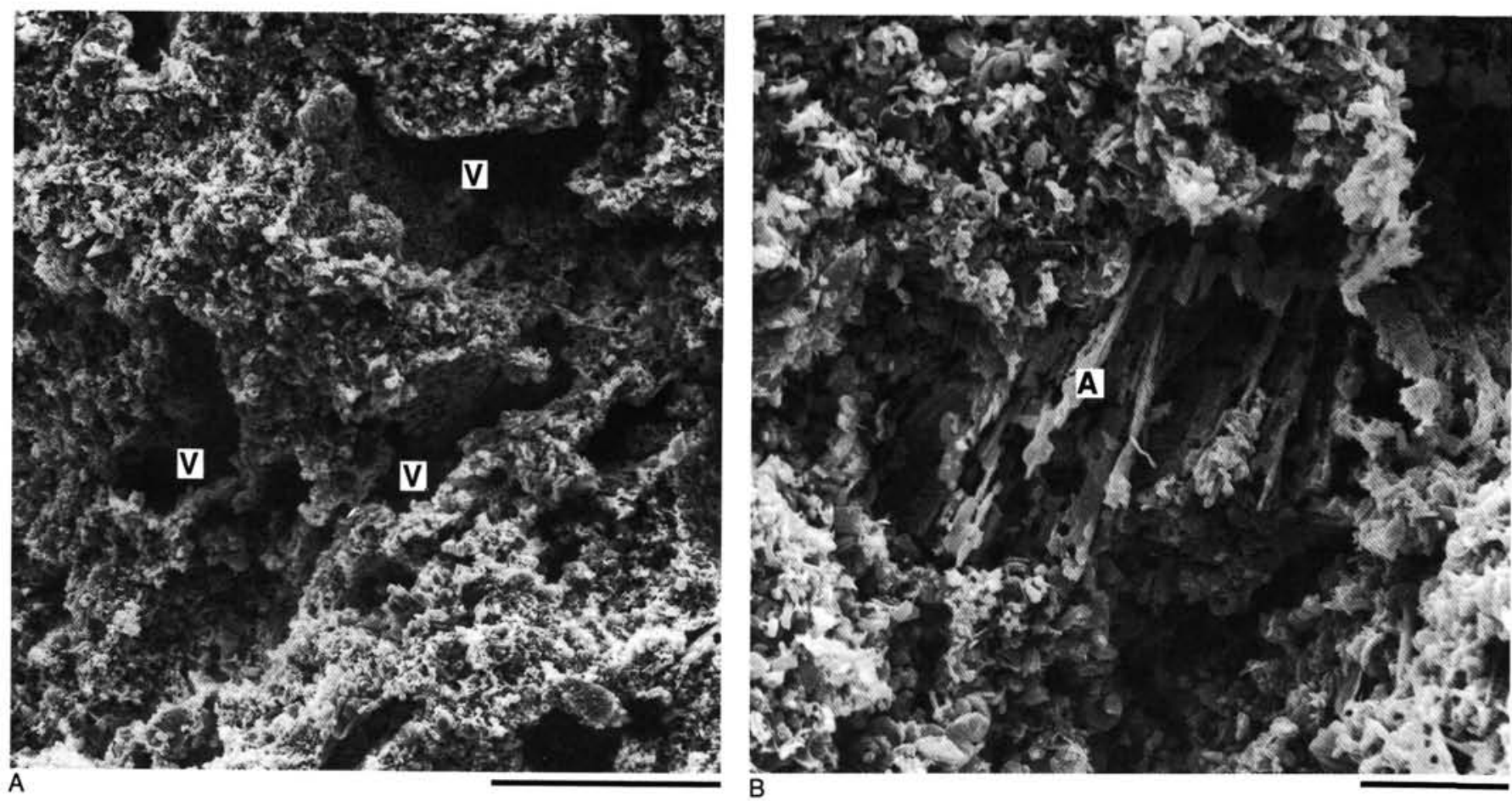

Figure 13. Origin of the vuggy porosity in Hole 630A. (A) Vuggy $(V)$ and moderately crystalline chalk at 111 mbsf (Sample 101-630A-12H-4, 108-110 $\mathrm{cm})$. Scale bar is $100 \mu \mathrm{m}$. (B) Skeletal allochem $(A)$, probably aragonitic and platform-derived, that is partially dissolved, yielding a vug similar in size and form to those of $\mathrm{A}$ in Holes 98 and 631 . Scale bar is $10 \mu \mathrm{m}$.

all, there is a good correlation $(r=0.89)$ between aragonite percentages and strontium concentrations.

Magnesium concentrations vary, ranging from about 5000 to a maximum of $24,000 \mathrm{ppm}$, and like strontium, can be viewed in a tripartite subdivision. In zone 1 ( $0-10 \mathrm{mbsf})$ magnesium values are relatively high, mimicking the magnesian calcite curve. In zone 2, between 10 and 85 mbsf (with the exception of two data points at 12 and $17 \mathrm{mbsf}$ ), magnesium concentrations gradually increase from about $6000 \mathrm{ppm}$ to $11,000 \mathrm{ppm}$, paralleling magnesian calcite and dolomite trends (Fig. 15). At about 85 mbsf (top of zone 3), magnesium values jump abruptly to about $13,500 \mathrm{ppm}$ and remain relatively high to the base of our sampling at 185 mbsf. However, a number of wide excursions are superimposed on the zone 3 trend for magnesium (Fig. 15), with values in excess of 17,000 to $19,000 \mathrm{ppm}$ and a maximum of $23,978 \mathrm{ppm}$. The overall increase in magnesium below $85 \mathrm{mbsf}$, along with the occurrence of authigenic dolomite, exceeds depositional magnesium concentrations from 0 to $85 \mathrm{mbsf}$. This suggests that part of the magnesium concentration forming dolomite probably is of allochthonous origin, with seawater as a possible source (Land, 1985).

Stable carbon-isotope ratios are markedly uniform throughout Hole 631A (Fig. 15). With the exception of a $1.4 \%$ depletion of $\delta^{13} \mathrm{C}$ in the top $10 \mathrm{~m}$ (zone 1$), \delta^{13} \mathrm{C}$ values for the remainder of the hole range between only +2.8 and $+3.0 \%$. However, the depletion of $\delta^{13} \mathrm{C}$ in zone 1 is consistent with trends observed at the other sites (Figs. 6 and 10).

Stable oxygen-isotope ratios display more variability here than in the other holes; in some cases, with abrupt enrichment and depletion of up to $2 \%$, which coincides $(r=-0.84)$ with zones of reduced aragonite content and increased calcite percentages (Fig. 15). In the upper $10 \mathrm{~m}$ (zone 1) an enrichment occurs in $\delta^{18} \mathrm{O}$ of from $0 \%$ to $+2.8 \%$, consistent with Holes 98 and $630 \mathrm{~A}$. Below $10 \mathrm{~m}$, a gradual downhole depletion to $0.8 \% 0$ occurs at a depth of 90 mbsf with the above described fluctuations. Below $90 \mathrm{mbsf}$, the oxygen ratio trend is relatively constant (Fig. 15).

\section{Microscopic Characteristics}

SEM observations indicate that aragonite needles are common in the upper $10 \mathrm{~m}$ of sediment (Fig. 16A). In regions of lowered aragonite, coccoliths and planktonic foraminifers are more abundant. At $43 \mathrm{mbsf}$, aragonite needles are rare, and coccoliths are heavily overgrown by subhedral crystals of calcite (Figs. 16B and 16C). Dissolution (?) vugs also occur by this subbottom depth, although primary, interstitial porosity appears to be retained (Fig. 16C). Below $75-80$ mbsf euhedral crystals of calcian-rich dolomite, less than $10 \mu \mathrm{m}$ in size, occur as voidfilled cement (Fig. 16D). Below $150 \mathrm{mbsf}$, well-indurated chalk alternates with poorly cemented ooze.

\section{Site Summary}

In terms of shallow-burial diagenesis, Hole 631A in Exuma Sound differs markedly from the other holes in the area. Lithification occurs quickly at shallow sub-bottom depths; yet, both aragonite and high-magnesian calcite persist to at least $185 \mathrm{mbsf}$. Because accumulation rates are much higher here, compared with ODP Sites 626 and 630 and DSDP Site 98 (Hollister, Ewing, et al., 1972; Austin, Schlager, et al., 1986), preservation of metastable minerals at depth may simply be a function of greater burial rate vs. diagenesis (Friedman, 1965). Oxygen-isotope ratios are enriched significantly in the upper $10 \mathrm{~m}$, indicating rapid equilibration with deep marine waters. Dolomite becomes common at about $80 \mathrm{mbsf}$, where a large increase in magnesium concentrations occurs, part of which may be derived from seawater.

Downhole, first-order mineralogical trends occur in discrete box-shaped steps, with superimposed high-amplitude, high-frequency, second-order fluctuations. Both orders may partly represent primary diagenetically modified depositional signals. Diagenetic overprints (lowered aragonite, increased calcite, enriched oxygen-isotope ratios) occur over narrow zones. This is the result of either (1) a higher initial diagenetic potential (caused by 

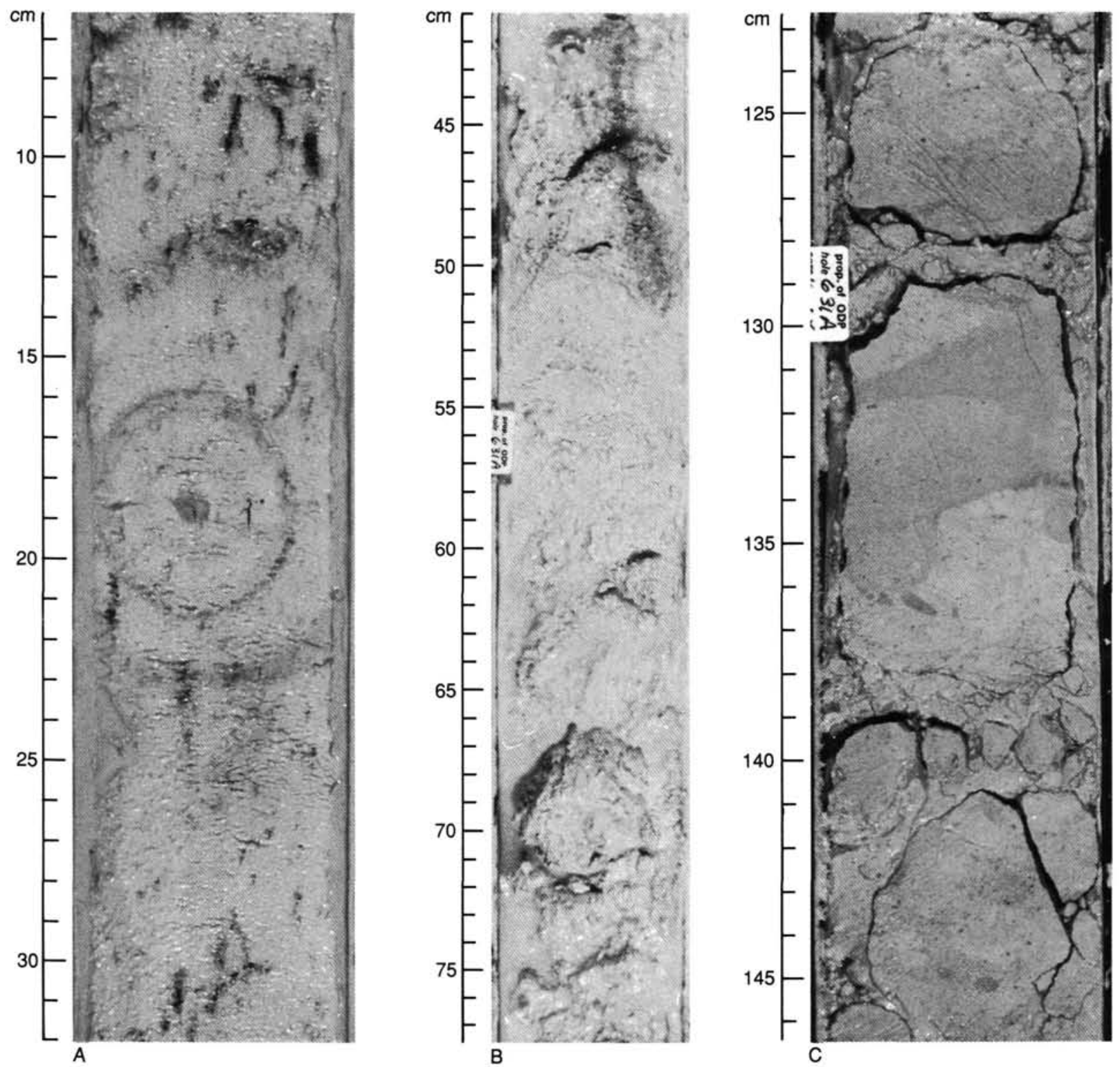

Figure 14. Selected photographs of Hole 631A cores. (A) Sample 101-631A-1H-2, 7-32 cm, purple banding "bulls-eye" in ooze. (B) Sample 101-631A-3H-1, 41-77 cm, soft to partially lithified ooze. (C) Sample 101-631A-16X-2, 123-146 cm, limestone to firm chalk having preserved bioturbation. A strong $\mathrm{H}_{2} \mathrm{O}$ odor was associated with these cores.

higher sedimentation rates) related to metastable components, including organic matter (Hesse, 1986), or (2) reduced sedimentation rates (beyond the present resolution of biostratigraphy), which would increase the amount of time (hence, potential for diagenetic alteration) that the sediment remained within a certain diagenetic subenvironment (James and Choquette, 1983a).

\section{DISCUSSION}

From our data base, a concept of two-stage, shallow-burial diagenesis for periplatform carbonates clearly emerges. First (stage 1), extensive diagenesis occurs rapidly in the upper $10 \mathrm{~m}$ of the sediment column. Stable oxygen isotopes are rapidly enriched up to $3 \%$, while carbon ratios become depleted by about $2 \%$. When studied with mineralogic data and trace element trends, nearsurface diagenesis apparently is in equilibrium with deep, cold, marine waters (Fig. 17). Further support for rapid diagenetic alteration, at least for holes north of Little Bahama Bank, comes from high magnesium and calcium gradients in interstitial pore water in the upper $10 \mathrm{~m}$ (Swart and Guzikowski, this volume) and from magnesium/calcium ratios below seawater stoichiometry (Austin, Schlager, et al., 1986; Swart and Guzikowski, this volume).

Below $10 \mathrm{mbsf}$, the rate of diagenetic change (stage 2) with burial decreases, as indicated by more gradual variations in stable-isotope ratios, carbonate mineralogy, and trace-element concentrations leading to stabilization, calcitization, and dolomitization. However, isotopic data indicate that the source of pore fluids is similar to that for stage 1 diagenesis (Fig. 17).

Our research approach delineated considerable regional variation in rates, styles, and degrees of burial diagenesis (Fig. 18). We interpreted these variations as being controlled by regional differences in seawater saturation (water depths), accumulation rates, primary influx of metastable components, and carbonate saturation of interstitial pore fluids. In their introduction to limestone diagenesis, James and Choquette (1983a) stated that "the degree to which any carbonate is altered... depends upon (1) the composition and flux of the water through the sediment or rock, and (2) the length of time the rock or stabilized sedi- 


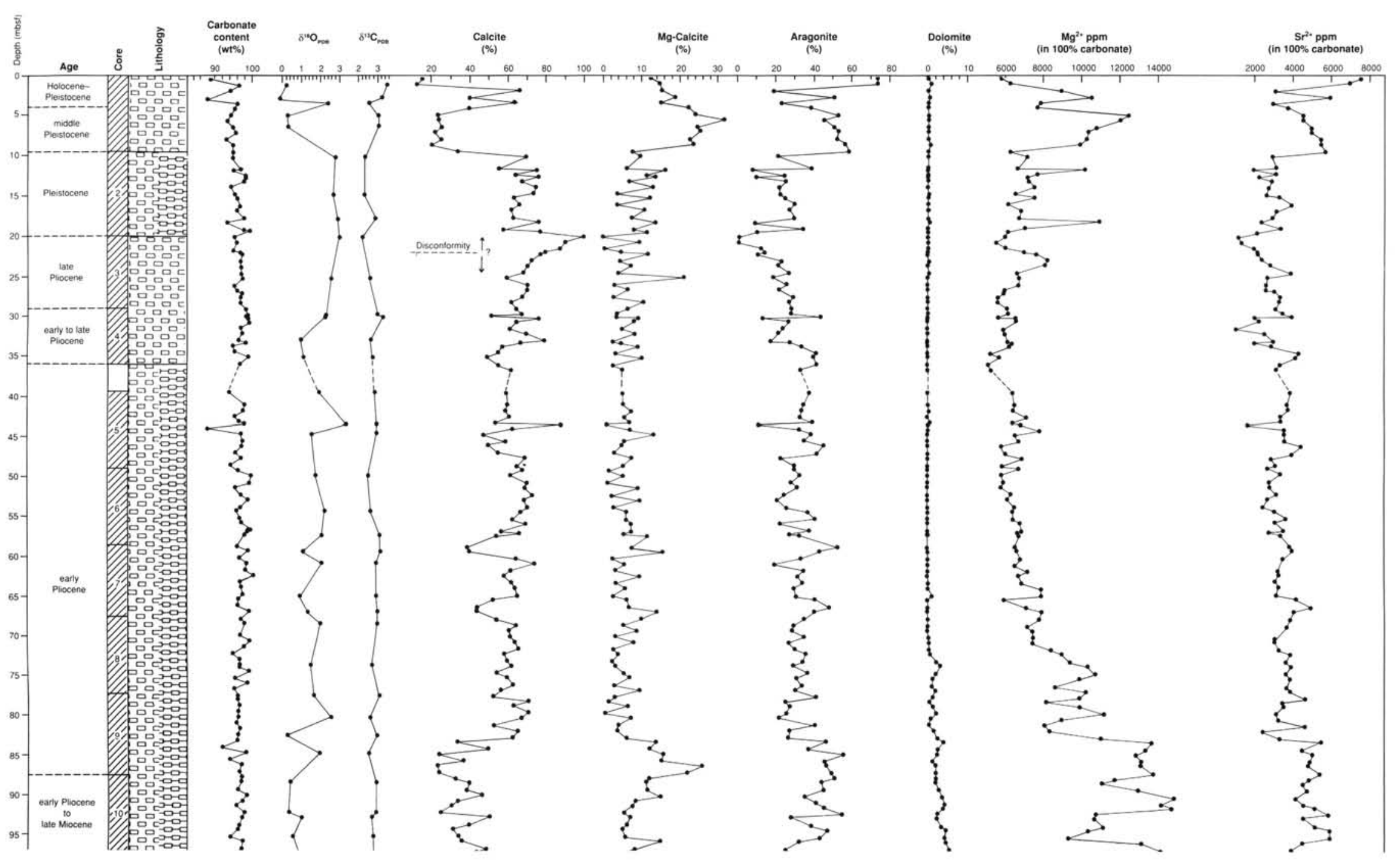




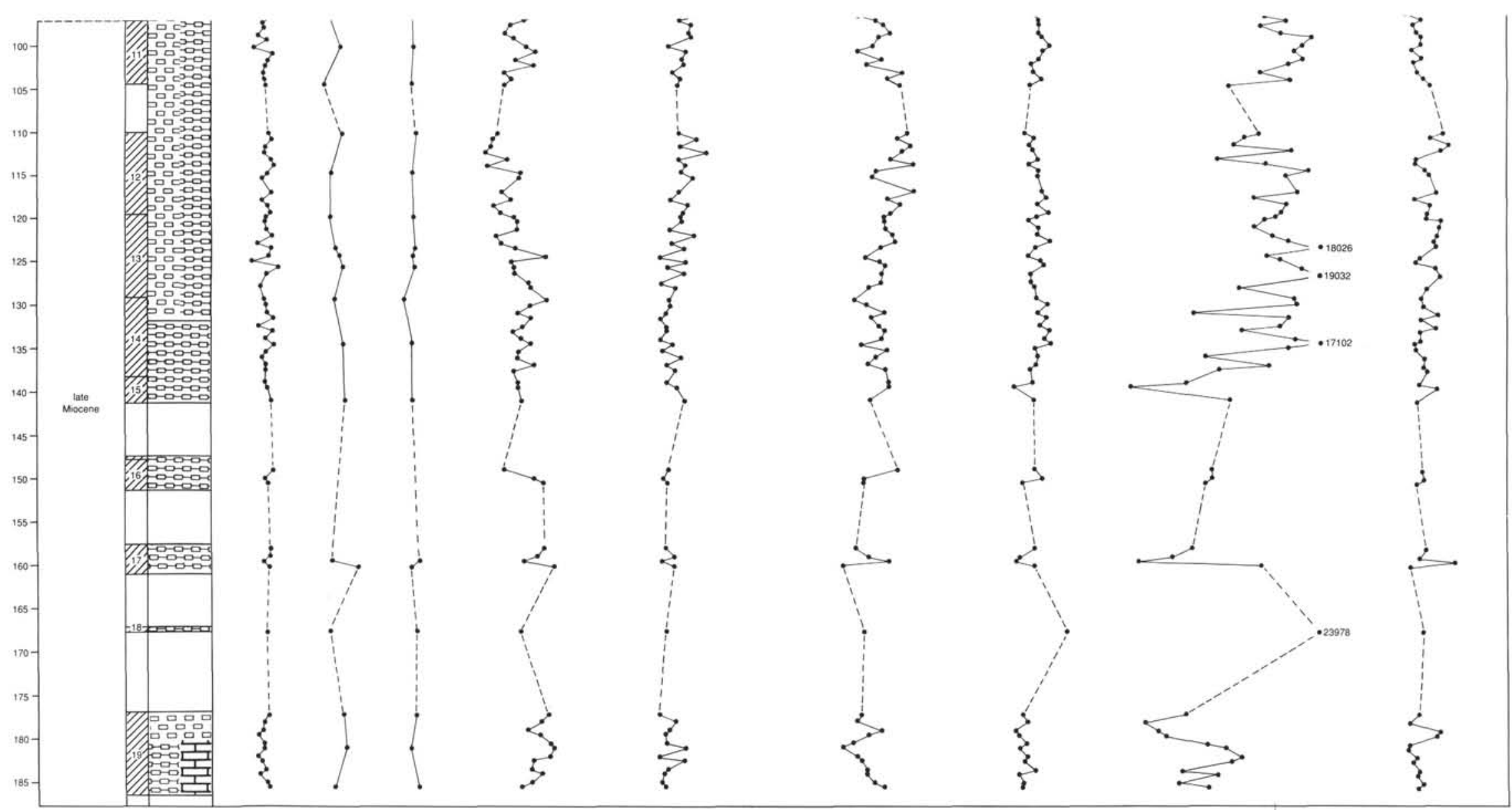

Figure 15. Quantitative mineralogy, carbonate content, geochemistry, and stable isotopes for Hole 631A. Core descriptions (see Fig. 2) taken from Austin, Schlager, et al. (1986). Lithologic symbols are those of Palmer et al. (1986, Fig. 8). 

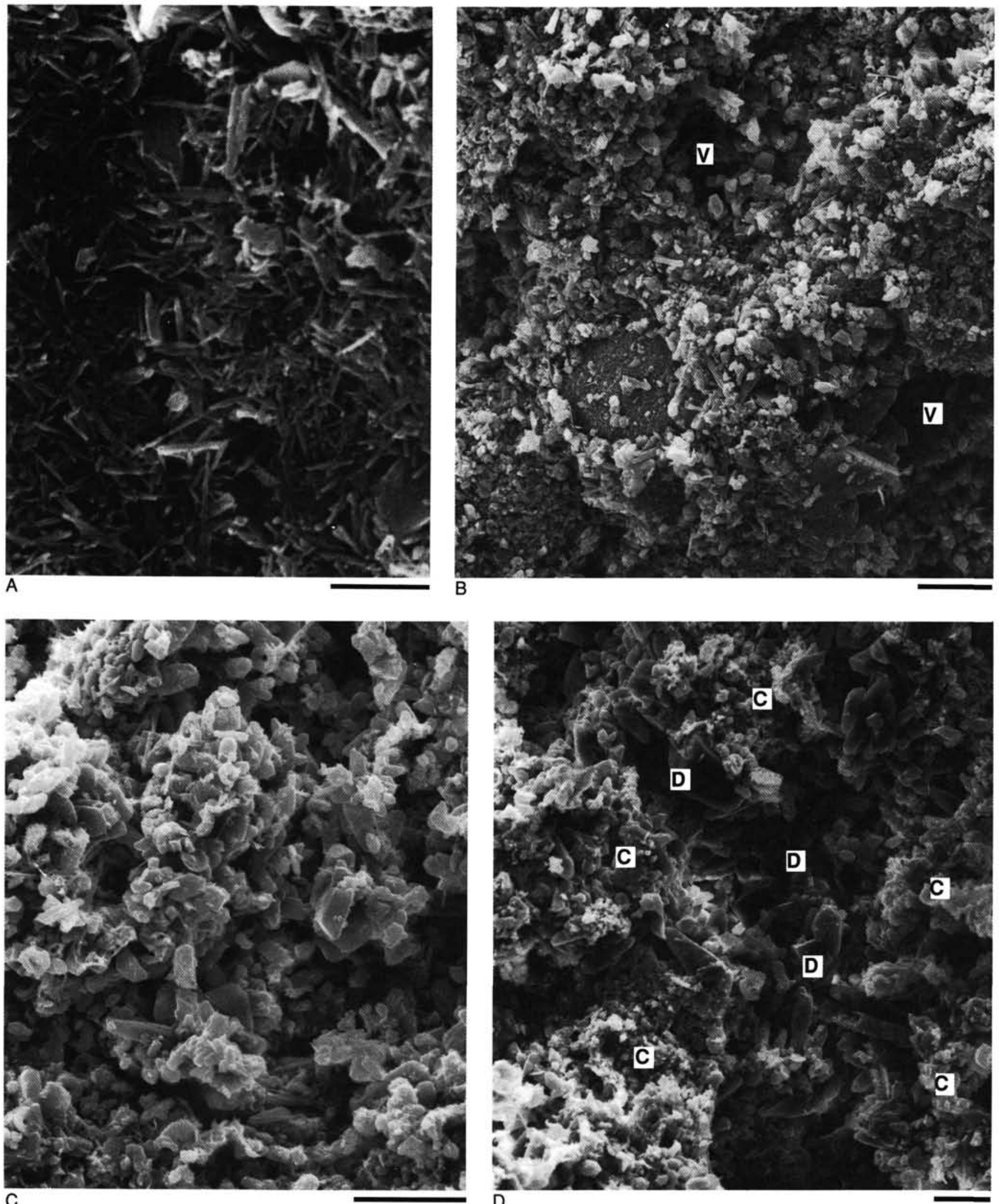

Figure 16. SEM photomicrographs of Hole 631A samples. (A) Typical aragonite needles showing little evidence of dissolution (Sample 101-631A$1 \mathrm{H}-1,40-42 \mathrm{~cm} ; 0.4 \mathrm{mbsf}$ ). Scale bar is $2 \mu \mathrm{m}$. (B) Vuggy nature of chalk at $43 \mathrm{mbsf}$ (Sample 101-631A-5H-3, 108-110 cm). This zone correlates with decreased aragonite, increased calcite, and enriched oxygen isotopes, indicating a zone of increased diagenesis. The vugs $(V)$ have an indeterminate origin but may be similar to those shown in Figure 14. Scale bar is $10 \mu \mathrm{m}$. (C) Diagenetic microcrystalline calcite of Figure 16B in a welllithified chalk. Scale bar is $10 \mu \mathrm{m}$. (D) Microcrystalline, euhedral dolomite (D) filling vugs in well-lithified chalk (C), sample (101-631A-19X-3, $108-110 \mathrm{~cm} ; 180.9 \mathrm{mbsf}$ ). Scale bar is $10 \mu \mathrm{m}$. 

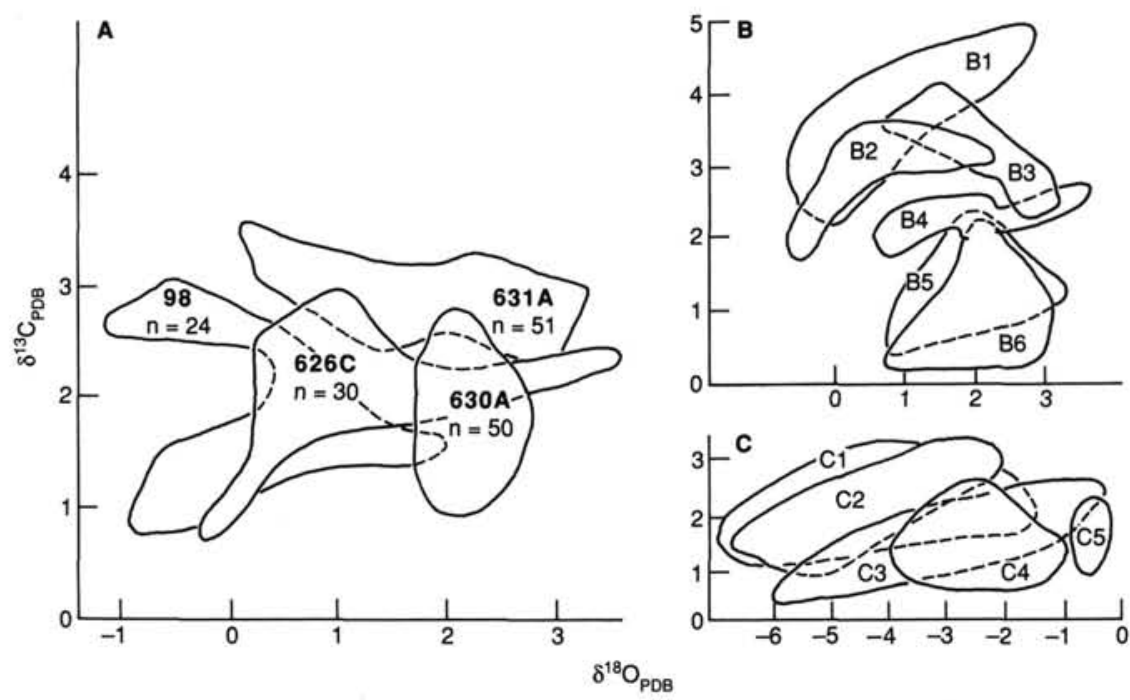

Figure 17. Distribution of carbon- and oxygen-isotope ratios for selected diagenetic carbonates. (A) DSDP Hole 98 and ODP Holes 626C, 630A, and 631A from this study. (B) Shallowto deep-water cements and hardgrounds: $\mathrm{B} 1=$ carbonate cements cited by James and Ginsburg (1979); B2 = deep-marine calcitic cement (Freeman-Lynde et al., 1986); B3 = hardgrounds, Tongue of the Ocean (Schlager and James, 1978); B4 = shallow sub-bottom chalk, north of Little Bahama Bank (Mullins et al., 1985a); B5 = pelagic hardgrounds (Milliman and Muller, 1977); B6 = pelagic hardgrounds (Milliman, 1966). (C) Chalk, on land, hardgrounds, and buried; $C 1=$ European chalk, cited by Schlager and James (1978); C2 = buried chalk from Leg 15 (Anderson and Schneidermann, 1975); C3 = field of average values for on-land chalk in Great Britain and North Sea (Scholle, 1974); C4 = buried chalk from DSDP Site 372 (McKenzie et al., 1978); C5 = chalk hardground, Leg 15 (Anderson and Schneidermann, 1975).

ment remains in the (diagenetic) environment" (p. 160). With respect to Bahamian Neogene periplatform carbonates, an additional control is the volume and temporal variation in depositional influx of metastable aragonite and magnesian calcite.

Evidence for extensive lithification, calcitization, and local dolomitization is presented for holes in the Florida Straits and north of Little Bahama Bank. These sites lie in 800 to $1100 \mathrm{~m}$ of water and have low-to-moderate accumulation rates $(<62 \mathrm{~m} /$ m.y.), but much less than the rates for Exuma Sound (commonly 82 to $210 \mathrm{~m} / \mathrm{m}$.y.) (Austin, Schlager, et al., 1986). We interpreted the gradual, but rapid, downhole alteration observed in Hole $630 \mathrm{~A}$ (below $10 \mathrm{mbsf}$ ) and the extensive calcitization and locally well-lithified intervals in Hole $626 \mathrm{C}$ as the result of only moderate burial rates relative to the high reactivity of the metastable components. This allows sufficient calcitization and lithification of metastable components in the shallow sub-bottom depths. Thin intervals of more altered sediment in Hole $626 \mathrm{C}$ may result from primary influx of larger volumes of metastable components related to sea-level variations and bank-top production (Boardman et al., 1986) or much lower rates of accumulation and, hence, episodic periods of exposure on the seafloor. Exposure at the seafloor, however, need not be a required factor (hardgrounds are not recognized-Austin, Schlager, et al., 1986) as circulation of seawater probably occurs through the upper few meters of sediments in this current-swept seaway.

DSDP Hole 98 displays low accumulation rates (generally less than $20 \mathrm{~m} / \mathrm{m} . y$.; Hollister, Ewing, et al., 1972). However, the water depth of $2750 \mathrm{~m}$ exceeds the magnesian calcite lysocline and is within a few hundred meters above the aragonite lysocline (Droxler et al., in press). Thus, we interpreted the rapid loss of metastable minerals in the upper 10 mbsf as more a function of undersaturation of interstitial pore fluids.

In contrast, we interpreted the preservation of abundant aragonite and magnesian calcite to at least $185 \mathrm{mbsf}$ in Hole 631 A as a function of greater accumulation rates that result in faster burial of metastable components vs. rates of diagenesis (dissolution and exsolution) (Friedman, 1965). In addition, rapid burial will trap seawater within the sediment column, which also may inhibit alteration. This is confirmed by pore-water magnesium/calcium ratios that are near seawater stoichiometry in the upper $100 \mathrm{~m}$ at sites in Exuma Sound (Swart and Guzikowski, this volume). Furthermore, the lack of notable magnesium and calcium gradients in interstitial pore fluids from Exuma Sound (Swart and Guzikowski, this volume) may be related to high sedimentation rates, as chemical gradients are in part inversely proportional to sedimentation rates (McDuff, 1981). Thin intervals of enhanced diagenesis (enriched oxygen isotopes, lowered aragonite, and increased calcite) represent either (1) lowered accumulation rates vs. alteration rates (i.e., a low ratio of burial/ diagenetic rates) or, more likely, (2) an initial higher diagenetic potential (more aragonite, high-magnesian calcite, and/or organic matter) leading to rapid alteration in the sediment column.

Both regional differences in accumulation rates and initial depositional mineralogical signature are controlled by the juxtaposition of shallow-water platforms and distance from the drill sites and bank tops (Heath and Mullins, 1984). Exuma Sound is surrounded on three sides by shallow-water platforms. The high accumulation rates provide abundant metastable components, which (even after lithification) are still present in significant quantities. Indeed, limestones and chalk at sites in Exuma Sound may be more susceptible to deeper, later stages of burial diagenesis because of retention of significant diagenetic potential (Dix and Mullins, unpublished data). This may lead to secondary vuggy porosity, which has obvious significance for the reservoir potential of periplatform carbonates.

Both stages 1 and 2 of diagenesis overprint primary depositional signals related to off-bank transportation and possible dissolution in relation to sea-level fluctuations and climatic variations (e.g., Droxler et al., 1983; Boardman et al., 1986). Stage 

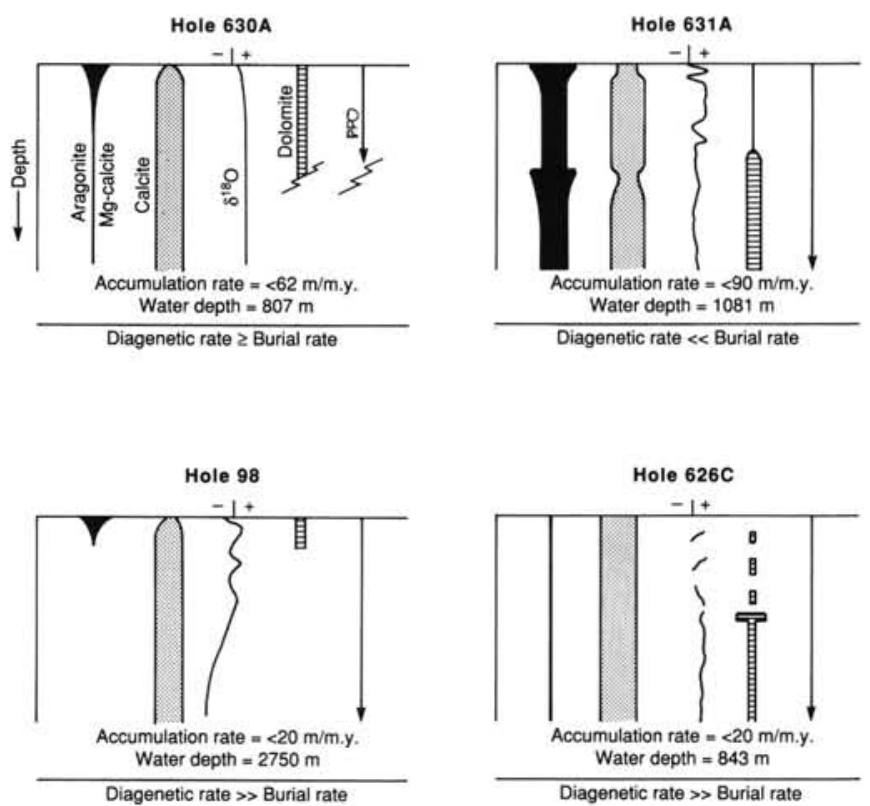

Figure 18. Idealized, sub-bottom trends in mineralogy and oxygen-isotope ratios for the four holes of this study, along with accumulation rates and water depths. Note that where accumulation rates are high (e.g., Hole 631A, Exuma Sound) metastable minerals are abundant at greater depth than in regions of low accumulation rates or in water depths that exceed the Mg-calcite lysocline (Hole 98, Northeast Providence Channel). These trends are interpreted in terms of attendant diagenetic rates vs. burial rates. All holes, except for the basal part of Hole $630 \mathrm{~A}$, are influenced by influx of periplatform ooze. Same symbols and identifying labels used for Hole 630 A are used for other holes; Mg-calcite $=$ high-magnesian calcite; $\mathrm{PPO}=$ periplatform ooze.

2 diagenesis appears to smooth out the initial diagenetic overprinting, which lowers the initial diagenetic potential. Diagenesis in the upper 200 mbsf yields isotopic signatures indicating marine-derived, relatively cold, pore fluids, as found for diagenetic shallow to deep-sea carbonate cements (Fig. 17).

With respect to previous studies about the diagenesis of periplatform carbonates, our data do not support the conclusions of Schlager and James (1978) that periplatform sediments remain unlithified in the burial diagenetic realm for "tens of millions of years." Our stage 1 diagenetic environment confirms the conclusions of Saller $(1984,1986)$, Mullins et al. (1985a, 1985b), and Freeman-Lynde et al. (1986) that rapid diagenesis and cementation can occur in the sediment column in the deep sea.

\section{COMPARISON WITH DEEP-SEA PELAGIC OOZE}

Because of the Deep Sea Drilling Project, we currently know a great deal about shallow-burial diagenesis of deep-sea pelagic oozes (reviewed by Garrison, 1981). However, unlike periplatform ooze, which initially contains large percentages of metastable carbonates, deep-sea pelagic carbonate ooze is essentially monomineralic ( $100 \%$ calcite) when first deposited.

In pelagic carbonate sequences little evidence for early diagenesis exists (Garrison, 1981). However, Kalin and Bernoulli (1984) suggested that lowered magnesium/calcium ratios of seawater before the onset of planktonic calcareous organisms may enhance shallow-burial diagenesis of purely calcitic pelagic sediment.

Based in part on the work of Schlanger and Douglas (1974), Matter et al. (1975) proposed a three-zone model for burial diagenesis of pelagic carbonates. In Zone I (0-50 mbsf), sediment consists of soft ooze with little, if any, evidence for dissolution; gravity compaction results in about a $10 \%$ loss of porosity. In Zone II (50-140 mbsf), stiff ooze develops, with strong evidence of dissolution and precipitated overgrowths. Decreases in both magnesium and strontium concentrations occur, and oxygen isotopes are depleted while carbon isotopes are enriched (Fig. 16). In Zone III ( $>140 \mathrm{mbsf}$ ), the first appearance of chalk occurs, followed by severe dissolution of planktonic foraminifers and some nannofossils (Garrison, 1981). The ultimate transition from chalk to limestone commonly occurs in the deep-burial realm of Schlanger and Douglas (1974), between 200 and 1000 mbsf.

Similar trends in gradual calcitization, lithification, and dissolution occur in periplatform carbonates, except that these trends occur much more rapidly and at considerably shallower burial depths. This is confirmed by more depleted oxygen-isotope ratios in monomineralic chalk (Fig. 17). The major difference between pelagic ooze and periplatform ooze is the initial diagenetic potential of periplatform carbonates that results from influx of metastable aragonite and high-magnesian calcite in deep waters of the periplatform realm. However, extensive shallow-burial diagenesis of periplatform carbonates, particularly in regions of low to moderately low accumulation rates, will greatly reduce their diagenetic potential to the point where the altered sediment may respond to further burial as if it were a monomineralic deep-sea pelagic ooze (e.g., DSDP Hole 98 and ODP Holes $626 \mathrm{C}$ and $630 \mathrm{~A})$.

\section{CONCLUSIONS}

1. Shallow-burial diagenesis of periplatform carbonates proceeds in two discrete stages. Stage 1 occurs in the top $10 \mathrm{~m}$ of the sediment column, where rapid, extensive diagenetic changes occur, including enrichment of oxygen isotopes, depletion of carbon isotopes, dissolution of aragonite, exsolution of magnesium from high-magnesian calcites, and incipient lithification. Stage 2 diagenesis (10-200 mbsf) is a slower, longer-term process of calcitization and lithification, gradual loss of magnesium and strontium, and isotopic equilibrium with still relatively cold, marine-derived pore waters.

2. Despite the commonality of stage 1 and 2 diagenesis, each of the examined holes displays different sub-bottom trends in mineralogy, geochemistry, and isotope ratios that reflect regional differences in physical and chemical oceanographic settings, variable mixtures of metastable and stable mineral components, differing rates of accumulation, and differences in the ratio of burial rates vs. diagenetic alteration and lithification.

3. A greater loss of metastable components during shallow burial at the sediment/water interface can be expected to occur in regions where diagenetic alteration is comparable with, or greater than, rates of burial (i.e., Florida Straits, north of Little Bahama Bank). In regions where water depth approaches lysoclinal boundaries (or the CCD), diagenetic alteration is enhanced by the undersaturation of seawater and interstitial pore fluids (Northeast Providence Channel). In regions of high accumulation rates, metastable components may be preserved at depth (e.g., 185 mbsf) because burial rates exceed rates of diagenetic alteration. These controls are first order and are overprinted by a second-order control related to diagenetic potential. Diagenetic potential is directly influenced by high-frequency depositional variations caused both by sea level and climatic fluctuations that affect bank-top production.

4. Compared with shallow-burial diagenesis of deep-sea pelagic ooze, periplatform ooze responds to diagenetic change much more quickly and at shallower burial depths.

\section{ACKNOWLEDGMENTS}

This paper represents part of G. Dix's Ph.D. dissertation at Syracuse University. Research was supported by a grant from USSAC to Henry 
Mullins, administered by the Texas A\&M Research Foundation, subcontracted from the Joint Oceanographic Institutions, Inc. Stable-isotope analyses for ODP samples were conducted at Brown University under the auspices of R. K. Matthews, and DSDP Hole 98 samples were conducted by Geochron Laboratories, Inc. We also thank Laura Dominguez and Dave Stephens for assistance in the laboratory. The manuscript was critically reviewed by James Austin, Jr., Noel James, Amanda Palmer, Wolfgang Schlager, and an anonymous reviewer.

\section{REFERENCES}

Anderson, T. F., and Schneidermann, N., 1973. Stable isotope relationships in pelagic limestones from the central Caribbean: Leg 13, Deep Sea Drilling Project. In Edgar, N. T., Saunders, J. B., et al., Init. Repts. DSDP, 15: Washington (U.S. Govt. Printing Office), 795803.

Austin, J. A., Jr., Schlager, W., et al., 1986. Proc. ODP, Init. Repts., 101: College Station, TX (Ocean Drilling Program).

Baker, P., Gieskes, J., and Elderfield, H., 1982. Diagenesis of carbonates in deep-sea sediments-evidence from $\mathrm{Sr} / \mathrm{Ca}$ ratios and interstitial dissolved Sr data: J. Sediment. Petrol., 52:71-82.

Bathurst, R.G.C., 1975. Carbonate Sediments and Their Diagenesis: Amsterdam (Elsevier).

Boardman, M. R., and Neumann, A. C., 1984. Sources of periplatform carbonates: Northwest Providence Channel. J. Sediment. Petrol., 54:1110-1123.

Boardman, M. R., Neumann, A. C., Baker, P. A., Dulin, L. A., Kenter, R. J., Hunter, G. E., and Kiefer, K. B., 1986. Banktop responses to Quaternary fluctuation in sea level recorded in periplatform sediments. Geology, 14:28-31.

Choquette, P. W., and Trussell, F. C., 1978. A procedure for making the titan-yellow stain for Mg-calcite permanent. J. Sediment. Petrol., 48:639-641.

Droxler, A. W., Schlager, W., and Whallon, C. C., 1983. Quaternary aragonite cycles and oxygen-isotope record in Bahamian carbonate ooze. Geology, 11:235-239.

Droxler, A. W., Morse, J. W., and Kornicker, W. A., in press. Controls on carbonate mineral accumulation in Bahamian basins and adjacent Atlantic Ocean sediments. J. Sediment. Petrol.

Evamy, B. D., 1969. The precipitational environment and correlation of some calcite cements deduced from artificial staining. J. Sediment. Petrol., 39:787-821.

Fischer, A. G., and Garrison, R. E., 1967. Carbonate lithification on the sea floor. J. Geol. Soc., 75:488-496.

Freeman-Lynde, R. P., Whitley, K. F., and Lohmann, K. C., 1986. Deep-marine origin of equant spar cements in Bahama Escarpment limestones. J. Sediment. Petrol., 56:799-811.

Friedman, G. M., 1965. Occurrence and stability relationships of aragonite, high-magnesian calcite and low-magnesium calcite under deepsea conditions. Geol. Soc. Am. Bull., 76:1191-1196.

Garrison, R. E., 1981. Diagenesis of oceanic carbonate sediments: a review of the DSDP perspective. Soc. Econ. Paleont. Mineral. Spec. Publ., 32:181-207.

Gomberg, D. N., and Bonatti, E., 1970. High magnesium calcite: leaching of magnesium in the deep sea. Science, 168:1451-1453.

Heath, K. C., and Mullins, H. T., 1984. Open-ocean, off-bank transport of fine-grained carbonate sediments in northern Bahamas. Geol. Soc. London Spec. Publ., 11:199-208.

Hesse, R., 1986. Diagenesis-11. Early diagenetic pore water/sediment interaction: Modern offshore basins. Geosci. Can., 13:165-196.

Hine, A. C., Wilber, R. J., Bane, J. M., Neumann, A. C., and Lorenson, K. R., 1981. Off-bank transport of carbonate sands along open, leaward bank margins: Northern Bahamas. Mar. Geol., 42:327-348.

Hollister, C. D., Ewing, J. I., et al., 1972. Init. Repts. DSDP, 11: Washington (U.S. Govt. Printing Office), 9-50.

Hook, J. E., Golubic, S., and Milliman, J. D., 1984. Micritic cement in microborings is not necessarily a shallow-water indicator. J. Sediment. Petrol., 54:425-431.

Hudson, J. D., 1977. Stable isotopes and limestone lithification. J. Geol. Soc., 133:637-660.

James, N. P., and Choquette, P. W., 1983a. Diagenesis-5. Limestones. Geosci. Can., 10:159-161.

1983b. Diagenesis-6. The sea floor diagenetic environment. Geosci. Can., 10:162-180.

, 1984. Diagenesis-9. Limestones-the meteoric diagenetic environment. Geosci. Can., 11:161-194.
James, N. P., and Ginsburg, R. N., 1979. The seaward margin of Belize barrier and atoll reefs. Int. Assoc. Sedimentol. Spec. Publ., 3:191.

Kalin, O., and Bernoulli, D., 1984. Schizosphaerella Deflandre \& Dangeard in Jurassic deeper-water carbonate sediments, Mazagan Continental Margin (Hole 547B) and Mesozoic Tethys. In Hinz, K., Winterer, E. L., et al., Init. Repts. DSDP, 79: Washington (U.S. Govt. Printing Office), 411-435.

Keir, J. S., and Pilkey, O. H., 1971. The influence of sea-level changes on sediment carbonate mineralogy, Tongue of the Ocean, Bahamas. Mar. Geol., 11:189-200.

Land, L. S., 1985. The origin of massive dolomite. J. Geol. Education, 33:112-125.

Matter, A., Douglas, R. G., and Perch-Nielsen, K., 1975. Fossil preservation, geochemistry and diagenesis of pelagic carbonates from Shatsky Rise, northwest Pacific. In Larson, R. L., Moberly, R., et al., Init. Repts. DSDP, 32: Washington (U.S. Govt. Printing Office), 891-922.

McDuff, R. E., 1981. Major cation gradients in DSDP interstitial waters: the role of diffusive exchange between seawater and upper oceanic crust. Geochim. Cosmochim. Acta, 45:1705-1713.

McKenzie, J., Bernoulli, D., and Garrison, R. E., 1978. Lithification of pelagic-hemipelagic sediments at DSDP Site 372: Oxygen isotope alteration with diagenesis. In Hsü, K. J., Montadert, L., et al., Init. Repts. DSDP, 41: Washington (U.S. Govt. Printing Office), 473478.

Milliman, J. D., 1966. Submarine lithification of carbonate sediments. Science, 153:994-997. lag). 1974. Marine Carbonates: Berlin-Heidelberg (Springer-Ver-

Milliman, J. D., and Muller, J., 1977. Characteristics and genesis of shallow-water and deep-water limestones. In Anderson, N. R., and Malahoff, A. (Eds.), The Fate of Fossil Fuel $\mathrm{CO}_{2}$ in the Oceans: New York (Plenum Press), 655-673.

Müller, G., and Gastner, M., 1971. The "Karbonat-Bombe," a simple device for the determination of the carbonate content in sediments, soils and other materials. Neues Jahrb. Mineral. Monatsh., 10: 466-469.

Mullins, H. T., and Lynts, G. W., 1976. Stratigraphy and structure of Northeastern Providence Channel, Bahamas: AAPG Bull., 60: 1037-1053.

Mullins, H. T., and Neumann, A. C., 1979. Deep carbonate bank margin structure and sedimentation in the northern Bahamas: Soc. Econ. Paleont. Mineral. Spec. Publ., 27:165-192.

Mullins, H. T., Neumann, A. C., Wilber, R. J., and Boardman, M. R., 1980. Nodular carbonate sediment on Bahamian slopes: possible precursor to nodular limestone. J. Sediment. Petrol., 50:117-131.

Mullins, H. T., Heath, K. C., Van Buren, H. M., and Newton, C. R., 1984. Anatomy of a modern open-ocean carbonate slope: northern Little Bahamas Bank. Sedimentology, 31:141-168.

Mullins, H. T., Wise, W. W., Jr., Gardulski, A. F., Hinchey, E. J., Masters, P. M., and Siegel, D. I., 1985a. Shallow subsurface diagenesis of Pleistocene periplatform ooze: Northern Bahamas. Sedimentology, 32:473-494.

Mullins, H. T., Land, L. S., Wise, W. W., Jr., Seigel, D. I., Masters, P. M., Hinchey, E. J., and Price, K. R., 1985b. Authigenic dolomite in Bahamian periplatform slope sediment. Geology, 13:292-295.

Palmer, A. A., Austin, J. A., Jr., and Schlager, W., 1986. Introduction and explanatory notes. In Austin, J. A., Jr., Schlager, W., et al., Proc. ODP, Init. Repts., 101: College Station, TX (Ocean Drilling Program), 5-23.

Saller, A. H., 1984. Petrological and geochemical constraints on the origin of subsurface dolomite, Enewetak Atoll: an example of dolomitization by normal seawater. Geology, 12:217-220.

1986. Radiaxial calcite in lower Miocene strata, subsurface Enewetak Atoll. J. Sediment. Petrol., 56:743-762.

Schlager, W., and James N. P., 1978. Low-magnesian calcite limestones forming at the deep-sea floor, Tongue of the Ocean, Bahamas. Sedimentology, 25:675-702.

Schlanger, S. O., and Douglas, R. G., 1974. The pelagic-ooze-chalklimestones transition and its implications for marine stratigraphy. Int. Assoc. Sedimentol. Spec. Publ., 1:117-148.

Scholle, P. A., 1974. Diagenesis of Upper Cretaceous chalks from England, Northern Ireland and the North Sea. Int. Assoc. Sedimentol. Spec. Publ., 1:177-210. 
Scholle, P. A., and Halley, R. B., 1985. Burial diagenesis: out of sight, out of mind. Soc. Econ. Paleontol. Mineral. Spec. Publ., 36:307334.
Date of initial receipt: 14 November 1986 Date of acceptance: 11 June 1987 Ms 101B-132 